\title{
De novo a data e o local de nascimento de Afonso I
}

Once again on the date and birthplace of Afonso I

\section{Abel Estefânio}

\section{(2) OpenEdition}

\section{Journals}

\section{Edição electrónica}

URL: http://journals.openedition.org/medievalista/996

DOI: 10.4000/medievalista.996

ISSN: 1646-740X

\section{Editora}

Instituto de Estudos Medievais - FCSH-UNL

\section{Refêrencia eletrónica}

Abel Estefânio, " De novo a data e o local de nascimento de Afonso I », Medievalista [Online], 19 | 2016, posto online no dia 01 junho 2016, consultado no dia 05 maio 2019. URL : http:// journals.openedition.org/medievalista/996 ; DOI : 10.4000/medievalista.996

(C) IEM 


\section{Medievalista onine}

Título: De novo a data e o local de nascimento de Afonso I I Once again on the date and birthplace of Afonso I

Autor: Abel Estefânio

Universidade: Investigador independente

Faculdade e Departamento / Unidade de Investigação: Investigador independente

Cidade: Porto

País: Portugal

Contacto: aestefanio@hotmail.com

Fonte: Medievalista [Em linha]. Dir. Bernardo Vasconcelos e Sousa. Lisboa: IEM.

Disponível em:

http://www2.fcsh.unl.pt/iem/medievalista/MEDIEVALISTA19/estefanio1906.html

ISSN: 1646-740X

Data recepção do artigo: 31 de Março de 2015

Data aceitação do artigo: 9 de Outubro de 2015

\section{Resumo}

Seja qual for o lugar em que nasceu D. Afonso Henriques, o nosso conhecimento acerca da sua importância histórica permanece o mesmo. Trata-se apenas de uma mera formalidade biográfica. Contudo, a investigação deste detalhe no plano científico pode ser importante para uma biografia dos seus pais. Implicando um exame minucioso do efetivo itinerário do conde D. Henrique e de D. Teresa, seguramente que ajudará a compreender melhor o seu papel político em uma conjuntura dominada por uma crise sucessória. A documentação do mosteiro de Sahagún veio trazer um aporte inesperado e decisivo para esse estudo, ao mesmo tempo que abriu a possibilidade de o nosso primeiro rei ter nascido no seio da corte de Leão e Castela.

Palavras-chave: Formação da nacionalidade, Mosteiro de Sahagún, Sucessão de Afonso VI, Henrique de Borgonha, Afonso Henriques. 


\section{Abstract}

Whatever the place where Afonso Henriques was born, our knowledge about its historical importance remains the same. It is just a mere biographical formality. However, the investigation of this detail in the scientific field may be important for a biography of his parents. Implying a thorough examination of the actual itinerary of Count Henry and Teresa, surely that will help to better understand their political role in an environment dominated by a succession crisis. The documentation of Sahagún Monastery has brought an unexpected and decisive contribution to this study, while opening the possibility of our first king having been born in the court of León-Castilla.

Keywords: Formation of the nationality, Sahagún Monastery, Succession of Alfonso VI, Henry of Burgundy, Afonso Henriques. 


\title{
De novo a data e o local de nascimento de Afonso I
}

\author{
Abel Estefânio
}

A José Mattoso

Certo cousa notavel he, que d'hum Rei tão famoso, e d'hum Rei Fundador como foi D. Affonço Henriques, se não saiba o anno em que nasceo. Mas eu ainda tenho por mais notável, que achando-se neste ponto os antigos Documentos coetâneos em oposição huns com outros, se canse muito os nossos modernos em querer descubrir $e$ fixar ao certo a Epoca daquele nascimento.

António Pereira de Figueiredo

L'historien n'est pas celui qui sait. Il est celui qui cherche.

Lucien Febvre

Passaram quase dois séculos sobre a publicação da frase do Padre António Pereira de Figueiredo, apresentada em epígrafe ${ }^{1}$. Podemos enquadrá-la numa tradição historiográfica de cariz positivista, largamente cultivada pela historiografia portuguesa, e não só, até à segunda metade do século XX, que foi perdendo, a partiir daí, expressão, quer em termos quantitativos, quer, sobretudo, qualitativos. A data e local do

${ }^{1}$ FIGUEIREDO, António Pereira de - "Dissertação XVII. Incerteza do anno em que nasceo ElRei D. Affonço Henriques, e certeza do anno, em que elle começou a reinar". in História e memórias da Academia Real das Sciencias de Lisboa. Tomo IX (1825), pp. 299-300.

Medievalísta online № 19| Janeiro - Junho 2016 @ IEM - Instituto de Estudos Medievais 3 
nascimento de Afonso Henriques deixou de ser matéria de interesse para os historiadores profissionais. O presente estudo retoma, assim, um tipo de investigação fundamental, umbilicalmente relacionado com a cada vez mais premente crítica de fontes.

Do interesse do tema creio não haver qualquer dúvida, atendendo a que não há biografia de D. Afonso Henriques ou manual de História de Portugal que não aponte um ano e um lugar de nascimento do nosso primeiro rei, ainda que se limitem a reproduzir tradições ou teses alheias, sem que esbocem qualquer tentativa de validação crítica. A explicação que encontro para esta situação tem a ver com o facto de os nossos historiadores atuais estarem mais vocacionados para fazer uma certa interpretação da História que para o escrutínio das fontes. Todavia, haverá sempre necessidade de revisitar as fontes quando pretendemos dar um incremento ao nosso conhecimento do passado.

O método de trabalho que vou utilizar é inspirado nos ramos científicos da Estatística e da Econometria, que me são familiares. A partir de um conjunto de pontos significativos, informações retiradas do que os historiadores designam por fontes, procuramos estimar uma «função envelope», ou seja, uma interpretação coerente com os dados que possuímos. Em alguns casos, detetando-se inconsistência ou mesmo contradição entre eles, procuramos justificar as opções tomadas, ao favorecer uns em detrimento de outros. É o que nos tratamentos estatísticos se refere por «limpeza dos dados», operação indispensável para evitar o que na gíria das ciências da informação se menciona por garbage in, garbage out. Para o perfeito funcionamento de um sistema computacional é necessário que não somente as suas funcionalidades estejam corretamente programadas, mas que também os dados de entrada sejam confiáveis. São funções comparadas com as que a Diplomática, a Codicologia ou a Paleografia exercem como ciências (ditas auxiliares) da História. Os resultados obtidos devem ser analisados pela qualidade do ajustamento da reconstituição histórica face aos dados disponíveis, que lhe serviram de suporte. Estamos a falar de probabilidades, tal como acontece nos estudos quantitativos ${ }^{2}$.

2 O facto de não conseguirmos estimar a probabilidade associada à reconstituição de um acontecimento numa escala de 0 a 1 não implica que não possamos fazer escolhas probabilísticas entre duas hipóteses

Medievalista online No 19| Janeiro - Junho 2016 (C) IEM - Instituto de Estudos Medievais 4 
Vamos começar por fazer uma breve revisão das conclusões do nosso trabalho anterior no qual consideramos como mais credível a informação de que Afonso Henriques nasceu em 1106. A partir deste resultado analisamos o itinerário do conde D. Henrique e de D. Teresa, com particular atenção para o período entre 1104 e 1109, mas não descurando as ilações que se podem tirar, quer do período anterior, quer do período que se seguiu. Concluiremos com uma proposta do local mais plausível onde poderia ter nascido o nosso primeiro rei.

\section{Resumo da proposta da data de nascimento de Afonso I}

É do mais elementar bom senso considerar que o sucesso da investigação do local onde possa ter nascido Afonso Henriques depende do ano em que nasceu. Dada a contradição existente entre fontes analísticas e cronísticas quanto a este ponto, estamos perante um problema de crítica textual. Num trabalho que publiquei na Revista Medievalista em $2010^{3}$, identifiquei um manuscrito do século XII, a Vita Theotonii, como a fonte mais antiga sobre a data de nascimento de D. Afonso Henriques. Como ela nos dá a informação que o rei tinha 56 anos quando São Teotónio morreu (18 de Fevereiro de 1162), dela se deduz o nascimento do nosso primeiro rei por volta de 1106 . Para além desta referência, verifiquei existirem ainda três fontes concordantes, a Translatio et Miracula S. Vincentii, o Indiculum Fundationis Monasterii Beati Vincentii Ulixbone e o Martirológio da Sé de Lisboa. Sendo que as duas primeiras foram produzidas ainda em vida do primeiro rei, podemos considerá-las como fontes independentes, o que lhes confere a maior credibilidade.

Pelo contrário, diria até em contrassenso, as fontes discordantes que identifiquei (os Annales D. Alfonsi Portugalensius Regis, os Annales Lamecenses, o Livro de Noa I e o

alternativas. Dada uma hipótese $\mathrm{H}_{1}$ com uma probabilidade $\mathrm{P}$ e uma hipótese alternativa $\mathrm{H}_{2}$ com a probabilidade complementar $\left(1\right.$ - P), aceitaremos $\mathrm{H}_{1}$ quando nos seja possível estimar para ela uma probabilidade $\mathrm{P}>(1-\mathrm{P})$. Sujeito, pois, ao juízo do leitor, as decisões probabilísticas que tomei, não só atendendo aos dados que se apresentam no presente trabalho mas também pelo teste de resistência a outras informações que considerem relevantes.

${ }^{3}$ ESTEFÂNIO, Abel - “A data de nascimento de Afonso I”. Medievalista [Em linha]. No 8 (Julho de 2010). [Consultado 31.01.2015]. Disponível em: http://www2.fcsh.unl.pt/iem/medievalista/MEDIEVALISTA8/estefanio8002.html.

Medievalista online NN 19| Janeiro - Junho 2016 (C) IEM - Instituto de Estudos Medievais 5 
De Expugnatione Scallabis) parecem ter derivado, direta ou indiretamente, da Vita Theotonii. Pelo menos assim o deduzo a partir de uma incompatibilidade entre o dia da semana em que esta fonte menciona que São Teotónio morreu, uma sexta-feira, e o dia do mês indicado, pois o dia 18 de fevereiro de 1162 foi um domingo. Como o ano em que faleceu não é apresentado de forma explícita no texto, a conjugação daqueles elementos levou alguns a fixarem a data da morte de Teotónio quatro anos mais tarde, dado que em 1166 o dia 18 de fevereiro foi, de facto, uma sexta-feira. Seria este o ano de referência responsável pela décalage de quatro anos no cálculo da data de nascimento de Afonso Henriques, fixando-a erroneamente em torno de 1110.

Considerando mais credível o nascimento de D. Afonso Henriques no ano de 1106, a ser verdadeira a notícia que se armou como cavaleiro quando tinha catorze anos, teria de se corrigir a sua efetiva datação de 1125, conforme consta dos Annales D. Alfonsi Portugalensius Regis, para 1120. Este ano pareceu-me perfeitamente aceitável porque é a partir dele que Afonso Henriques começa a outorgar ou subscrever a quase totalidade dos diplomas de D. Teresa ${ }^{4}$. Obviamente, este raciocínio pressupõe que a cerimónia se fizesse com o acordo da sua mãe. Do meu ponto de vista, este sincronismo entre as solenidades que envolvem a passagem à maioridade do jovem infante, que na época se situava nos catorze anos, não sendo um argumento decisivo, reforça a hipótese do nascimento em 1106.

Mantenho assim a posição que defendi há cinco anos. Desde então tenho sido frequentemente questionado sobre o lugar onde nasceu o nosso primeiro rei. $\mathrm{O}$ conhecimento das localidades em que o conde D. Henrique e D. Teresa estiveram contribuirá para formular uma hipótese credível.

\footnotetext{
${ }^{4}$ Em 18 de abril de 1120, Afonso Henriques confirma a carta de couto que D. Teresa outorga à Sé do Porto e ao seu bispo, D. Hugo (AZEVEDO, Rui de (ed.) - Documentos Medievais Portugueses, Documentos Régios, vol. I, Documentos dos condes portucalenses e de D. Afonso Henriques: A-D. 10951185. Lisboa: Academia Portuguesa de História, 1958-1962, t. I, doc. 53).
} 


\section{Os itinerários do conde D. Henrique e de D. Teresa}

Os historiadores portugueses têm assumido, sem necessidade de grandes demonstrações, que os condes portucalenses tiveram residência habitual em Guimarães, em Viseu e em Coimbra ${ }^{5}$. Sendo o lugar de nascimento do nosso primeiro rei disputado pelas três cidades, compreende-se que na sessão solene comemorativa dos 900 anos de nascimento de D. Afonso Henriques, realizada em Guimarães no dia 24 de Junho de 2009, o Presidente da República, Aníbal Cavaco Silva, procurasse acalmar as exacerbadas paixões bairristas, dizendo que o mais importante era que tinha nascido em terra que se tornou Portugal.

Todavia, não nos podemos contentar com essa afirmação, pois o historiador americano Bernard Reilly já tinha demonstrado cabalmente, a partir de fontes diplomáticas leonesas, que os condes portucalenses tiveram residência habitual junto da corte do reino de Leão e Castela ao longo de quase toda a primeira década do século XII ${ }^{6}$. É essa documentação que vamos agora passar a pente fino, com uma incidência maior nos anos mais próximos daquele que elegemos como o mais provável para o nascimento do nosso primeiro rei $^{7}$. O trabalho está algo facilitado porque o período em causa já foi por mim estudado no âmbito do célebre «pacto sucessório» realizado entre o conde D. Henrique e o conde D. Raimundo, que deu origem a dois artigos publicados na Revista Medievalista ${ }^{8}$.

\footnotetext{
5 AMARAL, Luís Carlos e BARROCA, Mário Jorge - A condessa-rainha Teresa. Lisboa: Círculo de Leitores, 2012, pp. 266-269. Pode-se encontrar nesta obra um magistral estudo da conjuntura em que nos situamos, que neste trabalho se apresenta de forma muito sintética e em que nos dispensamos de apresentar grandes referências, exceto nos casos em que consideramos necessário sublinhar ou aprofundar alguma particularidade e em todos os pontos que são fundamentais para informar o itinerário do conde D. Henrique e de D. Teresa. Agradeço aos Professores Doutores Luís Carlos Amaral e Mário Jorge Barroca a oferta do seu livro, logo após o seu lançamento, e a generosa resposta às várias solicitações de ajuda que fiz ao longo dos meus trabalhos.

${ }^{6}$ REILLY, Bernard F. - The Kingdom of León-Castilla under King Alfonso VI, 1065-1109. Princeton, Princeton University Press, 1988, p. 347.

${ }^{7}$ Exclui-se desta análise todos documentos considerados suspeitos ou falsos pelos editores das respetivas coleções diplomáticas, assim como aqueles que, por lhes ter sido atribuído um amplo intervalo de datação crítica, não contribuem para o esclarecimento dos itinerários do conde D. Henrique e de D. Teresa.

${ }^{8}$ ESTEFÂNIO, Abel - "Proposta de aclaração do 'pacto sucessório' à luz de novos dados". Medievalista [Em linha]. No 16 (Julho - Dezembro 2014). [Consultado 31.01.2015]. Disponível em: http://www2.fcsh.unl.pt/iem/medievalista/MEDIEVALISTA16/estefanio1603.html. e ESTEFÂNIO, Abel - “O 'pacto sucessório' revisitado: o texto e o contexto". Medievalista [Em linha]. No 10 (Julho de 2011). [Consultado 31.01.2015]. Disponível em:
} 
O mais antigo documento que nos informa com segurança da presença do conde D. Henrique na Península Ibérica encontra-se na coleção diplomática do mosteiro de Sahagún, publicada por Marta Herrero de La Fuente em 1988. Quer esse, de 9 de outubro de 1096, quer o seguinte, de 19 de janeiro de 1097, referem-no no protocolo de datação do documento como conde em Tordesilhas ${ }^{9}$. Note-se que nada se pode deduzir sobre o local onde o conde se encontrava nessas datas, mas não deixa de ser importante saber que tinha a tenência dessa localidade. Também não conseguimos averiguar se o título de conde e a tenência de Tordesilhas teriam sido concedidos a Henrique antes ou depois do seu casamento com Teresa ${ }^{10}$.

Em 25 de maio de 1098 aparece pela primeira vez na qualidade de confirmante num documento particular de Sahagún, identificando-se como genro do rei ${ }^{11}$. Só o voltamos a encontrar em 25 de janeiro de 1100 em Castrofruela (Leão), a confirmar, juntamente com D. Teresa, uma doação do rei Afonso VI ao mosteiro de Sahagún, com o título de conde portucalense ${ }^{12}$. Segue-se, nesse mesmo ano, a confirmação de documentos particulares a 13 e 27 de julho, 24 de novembro e 13 de dezembro ${ }^{13}$. Em 21 de março de 1101, juntamente com a mulher, fazem um escambo de bens com o mosteiro de Sahagún $^{14}$. No mês seguinte, encontramo-lo a confirmar dois documentos particulares, um a 6 e outro a 13 de abril ${ }^{15}$, sendo neste último caso acompanhado excecionalmente por D. Teresa, certamente por se tratar de um diploma produzido com grande solenidade

http://www2.fcsh.unl.pt/iem/medievalista/MEDIEVALISTA10/estefanio1002.html.

${ }^{9}$ HERRERO DE LA FUENTE, Marta (ed.) - Coleccion Diplomática del Monasterio de Sahagún (8571230). Vol. III (1073-1109). León: Centro de Estudios e Investigación «San Isidoro» (CSIC-CECEL), Caja de Ahorros y Monte de Piedad, Archivo Histórico Diocesano, 1988, docs. 987 (comes domno Ancricco in Auctario de Sellas) e 996 (Comes domno Enrriz in Otero de Sellas), respetivamente.

${ }^{10}$ De acordo com REILLY, Bernard F. (The Kingdom of León-Castilla under King Alfonso VI, op. cit., p. 255), o casamento do conde D. Henrique com D. Teresa ter-se-ia realizado nos últimos meses de 1096. Esta cronologia não é segura porque se apoia no ano do foral outorgado a Constantim de Panóias, que se conhece apenas através de apógrafos (AZEVEDO, Rui de (ed.) - op. cit., t. I, doc. 3 (1096)). Recorde-se que o diploma de Afonso VI para o mosteiro de S. Servando, cuja data de 13 de fevereiro de 1095 serviu de base a AZEVEDO, Rui de (op. cit., t. I, p. XVIII, nota 1) para supor que o casamento se pudesse ter realizado mais cedo, encontra-se atualmente redatado criticamente de 1098 ou 1099 (REILLY, Bernard F. - op. cit., p. 261, nota 4 e GAMBRA, Andrès - Alfonso VI. Cancillería, Cúria y Império. León: Centro de Estudios e Investigacíon San Isidoro/Achivo Histórico Diocesano de León, 1997-1998, II, doc. 152).

${ }^{11}$ HERRERO DE LA FUENTE, Marta (ed.) - op. cit., doc. 1029: "Henriccus gener regis conf.".

12 Ibidem, doc. 1045 e GAMBRA, Andrès - op. cit., II, doc. 155: "Henriccus Portucalensis comes conf. Vxor ipsius Taresa filia regis conf.".

${ }^{13}$ HERRERO DE LA FUENTE, Marta (ed.) - op. cit., docs. 1055, 1057, 1060 e 1061, respetivamente.

${ }^{14}$ Ibidem, doc. 1067 e AZEVEDO, Rui de (ed.) - op. cit., t. I, doc. 7.

${ }^{15}$ HERRERO DE LA FUENTE, Marta (ed.) - op. cit., docs. 1068 e 1069, respetivamente. 
do conde Pedro Ansures, um dos mais próximos colaboradores do rei Afonso VI. Voltamos a encontrar o conde D. Henrique a confirmar um documento particular de 6 de março de 1102 e dois em 25 de fevereiro de $1103^{16}$.

Para além destes documentos da coleção do mosteiro de Sahagún, o estudo mais detalhado do itinerário do conde D. Henrique e de D. Teresa antes de 1104, que transcende o objetivo deste trabalho, obrigaria ainda a considerar registos cronísticos que dão conta da presença do conde D. Henrique, em 16 de setembro de 1101, na Batalha de Malagón, onde foi derrotado pelas forças almorávidas, e da sua participação em novos recontros com os almorávidas em Castela no ano de $1102^{17}$, quinze diplomas da chancelaria de Afonso VI onde o conde aparece na qualidade de confirmante ${ }^{18}$, seis documentos condais por ele outorgados ${ }^{19}$ e dois documentos particulares «portugueses». $\mathrm{O}$ primeiro destes últimos, datado de maio de $1103^{20}$, informa que o conde se encontrava nessa ocasião em Jerusalém, o que seria manifestamente impossível dado o curto intervalo de tempo entre o já referido documento de Sahagún, de 25 de fevereiro de 1103, e o segundo documento particular, uma doação aos condes de bens situados perto de Guimarães, em 11 de julho de $1103^{21}$. O documento seguinte, em que D.

${ }^{16}$ Ibidem, docs. 1081, 1092 e 1094, respetivamente.

${ }^{17}$ Conforme REILLY, Bernard F. - The Kingdom of León-Castilla under King Alfonso VI, op. cit., pp. 299, 312-313.

${ }^{18}$ GAMBRA, Andrès - op. cit., II, docs. 145 (17 de abril de 1098), 147 (17 de janeiro de 1099), 151 ([2] de fevereiro de 1099), 152 (13 de fevereiro de [1098-1099]), 153 (14 de março de 1099), 156 (15 de abril de 1100), 157 (22 de abril de 1100), 159 (18 de agosto de [1100]), 160 (20 de agosto de [1100], Bustillo de Castrofruela), 161 (1100), 163 (20 de março de 1101), 169 (17 de janeiro de [1102-1103]), 170 (20 de janeiro de 1103), 171 (10 de fevereiro de 1103, Cea) e 178 (12 de dezembro de [1103]).

${ }_{19}$ AZEVEDO, Rui de (ed.) - op. cit., t. I, docs. 1 ([1095-1096]), 3 (1096), 4 (23 de novembro de 1097), 5 (9 de dezembro de 1097), 6 (março de 1100, Coimbra) e 8 (8 de junho de 1101).

${ }^{20}$ AZEVEDO, Rui de (ed.) - Documentos Medievais Portugueses, Documentos Particulares. Vol. III, AD. 1101-1115. Lisboa: Academia Portuguesa de História, 1940, doc. 112 (maio de 1103): “(...) ad uenitam comitis de Iherusalem ubi erat (...)". Sobre esta referência que coloca D. Henrique em Jerusálem, houve quem sugerisse que o conde teria saído da Península para se associar a uma cruzada planeada por Henrique IV, imperador do Sacro Império Romano-Germânico, que não teve seguimento, pela oposição que lhe moveu o papa Pascoal II (1099-1118) (Grande Enciclopédia Portuguesa e Brasileira. Vol. XIII. Lisboa-Rio de Janeiro:Editorial Enciclopédia, s.d., verbete "Henrique (D.)"). Outros autores sugeriram que o conde, a pretexto de uma ida a Jerusalém, teria acompanhado São Geraldo na viagem que este fez em 1103 a Roma para se avistar com o papa e tentar resolver a questão em torno dos direitos metropolitas da Sé de Braga (Conforme AMARAL, Luís Carlos e BARROCA, Mário Jorge - op. cit., p. 42).

${ }^{21}$ No documento de 11 de julho de 1103, Mendo Viegas, Gomes Nunes e Toda Eitat dão ao conde D. Henrique, a sua mulher D. Teresa e ao mosteiro de Guimarães bens que possuem em Pousada, no concelho de Guimarães, em troca de um quinhão no mosteiro de Pombeiro (AZEVEDO, Rui de (ed.) -

Medievalista online № 19| Janeiro - Junho 2016 (C) IEM - Instituto de Estudos Medievais 9 
Henrique e D. Teresa aparecem novamente na corte a confirmar uma permuta entre o conde D. Raimundo e o bispo de Oviedo, é de outubro de $1103^{22}$. Verificamos que, neste caso, o intervalo de tempo entre os dois documentos leoneses é mais que suficiente para que entretanto tenham feito uma visita aos seus domínios, pelo que é admissível que estivessem presentes na outorga da doação de bens em Guimarães, de que eram os beneficiários.

É consensual que no ano de 1104 o conde D. Henrique e D. Teresa permaneceram ausentes do Condado Portucalense. Não só não aparecem na documentação condal, como se deteta a presença continuada de D. Henrique ao longo de todo ano no reino de Leão. De acordo com a documentação do mosteiro de Sahagún, o conde confirma documentos particulares a 9 de fevereiro, 4 de março, 9 de maio, 13 de junho e 13 de setembro ${ }^{23}$.

Entrando no ano de 1105, merece uma referência especial um documento publicado por outro historiador americano, Charles Julian Bishko, no qual o conde D. Henrique e D. Teresa fazem uma doação ao mosteiro de Santo Isidro de Dueñas, em 30 de janeiro ${ }^{24}$. O documento em causa foi redigido pelo notário régio Paio Eriges e a comparência entre o elevado número de quarenta e três confirmantes - para além de próceres portugueses de um conde ${ }^{25}$, três tenentes de terra, três bispos, três abades e três priores, todos eles leoneses, mostra bem a capacidade mobilizadora que o conde possuía em Terra de Campos.

op. cit., t. III, doc. 125): “(...) ad uobis comite domno Anriko et uxor uestra domna Tareiga... ut faceremus uobis comite domno Anrico et uxor eius domna Tarasia et frates de Vimaranes (...)".

${ }_{22}$ Conforme REILLY, Bernard F. - The Kingdom of León-Castilla under King Alfonso VI, op. cit., p. 317, com a referência na nota 61 a GARCIA LARRAGUETA, Santos (ed.) - Colección de documentos de la catedral de Oviedo. Oviedo, 1962, p. 331. Em REILLY, Bernard F. (ibidem) encontra-se ainda uma outra referência à presença do conde $\mathrm{D}$. Henrique como confirmante, numa doação do conde Pedro Ansures ao bispo Raimundo de Palença, em 7 de novembro de 1103. Tanto num caso como no outro, o lugar de emissão não é evidente.

${ }^{23}$ HERRERO DE LA FUENTE, Marta (ed.) - op. cit., 1988, docs. 1101, 1102, 1105, 1108 e 1114 , respetivamente.

${ }^{24}$ BISHKO, Charles Julian - "Count Henrique of Portugal, Cluny and the antecedents of the Pacto Sucessório". in Revista Portuguesa de História, 13 (1971), pp. 155-188. Reedição, com nota adicional, em Spanish and portuguese monastic history: 600-1300. London, 1984, IX, pp. 166-167.

${ }^{25}$ Trata-se do conde Martin Laínez, um dos assessores mais acreditados do rei Afonso VI a partir de 1090, que morreu provavelmente na batalha de Uclés (GAMBRA, Andrès - op. cit., I, p. 582).

Medievalísta online $N^{\circ} 19 \mid$ Janeiro - Junho 2016 (C) IEM - Instituto de Estudos Medievais 10

www2.fcsh.unl.pt/iem/medievalista 
É muito interessante saber que duas semanas antes, a 16 de janeiro de 1105 , o conde D. Raimundo e a sua mulher D. Urraca tinham feito uma doação ao mosteiro de São João de Poio, que se situa junto a Pontevedra. A outorga deste documento, que foi por mim recentemente publicado ${ }^{26}$, contou igualmente com um elevado número de confirmantes. Nessa ocasião, D. Urraca estava no oitavo mês da gravidez de Afonso Raimundes que, como se sabe, viria a nascer perto do mosteiro, em Caldas de Reis.

Não posso deixar de ligar a concessão deste privilégio ao nascimento de Afonso Raimundes, a 1 de março de $1105^{27}$, como sendo a expressão de um voto para um parto bem-sucedido, assim como também não posso deixar de considerar que o conde D. Henrique, com a sua doação, pudesse ter motivações semelhantes às do seu primo ${ }^{28} \mathrm{e}$ cunhado. Ambos queriam ter uma palavra na sucessão ao trono de Leão e Castela, conforme se depreende do «pacto sucessório» que realizaram em confrontação direta com as pretensões do rei Afonso VI relativamente ao seu filho Sancho, legitimado pelo casamento com a sua concubina Zaida, que tomou o nome cristão de Isabel $^{29}$. O pacto atribui a D. Henrique o papel de assegurar o reino de Leão e Castela para D. Raimundo, em troca de contrapartidas substanciais. É digna de nota a interpretação de Bernard Reilly, de que tal pressupunha que Raimundo pudesse estar longe, na Galiza, e que Henrique estivesse em Leão onde podia tomar a iniciativa e não longe, em «Portugal» ${ }^{30}$. Nos dias 1 e 2 de junho desse ano, o conde D. Henrique confirma documentos do mosteiro de Sahagún ${ }^{31}$. Em 11 de setembro, aparece novamente a confirmar mais um documento da mesma origem ${ }^{32}$. A 22 do mesmo mês confirma um documento real da catedral de Burgos, sendo que neste último surge acompanhado por D. Teresa, o que

${ }^{26}$ ESTEFÂNIO, Abel - "Um documento significativo para a história da Galiza". in Annuarium Sancti Iacobi, 2 (2013), pp. 17-30.

${ }^{27}$ Conforme REILLY, Bernard F. - The Kingdom of León-Castella under Queen Urraca (1109-1126). Princeton: Princeton University Press, 1982, p. 45, nota 2.

${ }^{28}$ Henrique e Raimundo eram primos afastados pelo facto de terem bisavôs irmãos (AMARAL, Luís Carlos e BARROCA, Mário Jorge - op. cit., pp. 50-51).

${ }^{29}$ Ibidem, pp. 58-59.

${ }^{30}$ REILLY, Bernard F. - The Kingdom of León-Castilla under King Alfonso VI, op. cit., p. 252.

${ }^{31}$ HERRERO DE LA FUENTE, Marta (ed.) - op. cit., docs. 1123 e 1124, respetivamente. O primeiro destes documentos, por se tratar de um litígio cuja resolução foi feita na presença do rei Afonso VI, foi também publicado por GAMBRA, Andrès - op. cit., II, doc. 183. Acerca da presença frequente do conde D. Henrique nos diplomas de Afonso VI, dada pela confirmação de vinte e uma escrituras entre 1098 e 1107 (incluindo nesta contagem um falso), consulte-se AMARAL, Luís Carlos e BARROCA, Mário Jorge - op. cit., pp. 158-159.

${ }^{32}$ HERRERO DE LA FUENTE, Marta (ed.) - op. cit., doc. 1127. 
não acontece quando se trata da confirmação de documentos particulares ${ }^{33}$. Em 13 de dezembro voltamos a encontrar apenas o conde D. Henrique a confirmar dois documentos particulares de Sahagún ${ }^{34}$.

Em 1106, o conde mantem-se em Sahagún, confirmando documentos em 10, 12, 16 e 22 de janeiro, em 19 de fevereiro e em 4 de março ${ }^{35}$. A 19 de março confirma, juntamente com D. Teresa, um documento régio da catedral de Oviedo ${ }^{36}$. Em 10 de junho e em 28 de julho, volta a confirmar documentos particulares de Sahagún ${ }^{37}$. Sendo o último destes um original que nos merece toda a confiança, torna impossível que o conde D. Henrique se tenha deslocado a Seia, a 1 de Agosto, para a doação da herdade de São Romão aos presbíteros João e Fáfila ${ }^{38}$. Pelo que também não me parece credível que no dia 25 do mesmo mês se tenha deslocado ao Condado Portucalense para a doação de Cacia ao mosteiro de São Mamede de Lorvão ${ }^{39}$. Conhecemos este último documento a partir de uma cópia que contém interpolações assinaladas por Rui de Azevedo, que o levaram a admitir que a doação até podia ter sido efetuada em data posterior à que consta no documento, eventualmente quando D. Teresa era já viúva ${ }^{40}$. Em 7 de novembro, voltamos a encontrar o conde D. Henrique a confirmar um documento particular de Sahagún ${ }^{41}$.

No início do ano de 1107 o conde D. Henrique continua em Sahagún, como se pode depreender de uma confirmação de um documento particular de 18 de Janeiro ${ }^{42}$. Em 14

${ }^{33}$ GAMBRA, Andrès - op. cit., II, doc. 184.

${ }^{34}$ HERRERO DE LA FUENTE, Marta (ed.) - op. cit., docs. 1128 e 1129, respetivamente.

${ }^{35}$ Ibidem, docs. 1132, 1133, 1134, 1135, 1137 e 1139, respetivamente.

${ }^{36}$ GAMBRA, Andrès - op. cit., II, doc. 185.

${ }^{37}$ HERRERO DE LA FUENTE, Marta (ed.) - op. cit., docs. 1145 e 1146.

${ }^{38}$ AZEVEDO, Rui de (ed.) - Documentos Medievais Portugueses, Documentos Régios, vol. I, t. I, doc. 10. Devo referir que REILLY, Bernard F. (The Kingdom of León-Castilla under King Alfonso VI, op. cit., p. 322 e nota 91) lançou suspeita sobre o documento de Sahagún de 28 de julho devido à proximidade de data com o documento condal, por julgar que a outorga deste implicaria a deslocação dos condes a «Portugal», o que não considero procedente. $\mathrm{O}$ meu atrevimento, neste pormenor, perante o ilustre historiador, cujo trabalho está na génese do meu, deve-se à vantagem de dispormos atualmente de um maior número de fontes publicadas. Mas, mesmo na hipótese de D. Henrique e D. Teresa se terem deslocado pontualmente ao condado no verão de 1106, possibilidade que considero muito remota, o facto não colocaria em causa a evidência de uma presença continuada dos condes na corte do reino de Leão.

${ }^{39}$ AZEVEDO, Rui de (ed.) - op. cit., t. I, doc. 11.

${ }^{40}$ Ibidem, t. II, nota X (doc. 32), contendo uma reapreciação crítica do doc. 11.

${ }^{41}$ HERRERO DE LA FUENTE, Marta (ed.) - op. cit., doc. 1149.

${ }^{42}$ Ibidem, doc. 1150.

Medievalista online № 19| Janeiro - Junho 2016 @ IEM - Instituto de Estudos Medievais 12

www2.fcsh.unl.pt/iem/medievalista 
de abril outorga, juntamente com o rei Afonso VI e o filho deste, o infante Sancho, foros e isenções aos povoadores de "Ripa de Tera et de Villaviride" ${ }^{43}$. Em maio, juntamente com D. Teresa, confirmam um documento régio em Monzón ${ }^{44}$, no dia 8, e outro em Burgos ${ }^{45}$, no dia 14, no qual Sancho aparece como "regnum electus patri factum, 46 . Volta a confirmar, sem ser acompanhado pela mulher no ato, documentos particulares de Sahagún em 12 de junho, 27 de julho e em 7 e 27 de Agosto ${ }^{47}$.

O falecimento da rainha Isabel durante um parto mal sucedido em 12 de setembro de $1107^{48}$ e a morte do conde D. Raimundo, oito dias depois ${ }^{49}$, envolveriam grandes

${ }^{43}$ CAVERO DOMÍNGUEZ, Gregoria e MARTIN LÓPEZ, Encarnación - Colección Documental de la Catedral de Astorga I (646-1126). Léon: Centro de Estudios e Investigacíon San Isidoro/Achivo Histórico Diocesano de León, 1999, doc. 534, pp. 396-397. Citado por SALAZAR Y ACHA, Jaime de "De nuevo sobre la mora Zaida". in Hidalguia, 321 (2007), p. 241. O documento encontra-se omisso nas coleções diplomáticas do rei Afonso VI e do conde D. Henrique (ou seja, em GAMBRA, Andrès - $o p$. cit., II e AZEVEDO, Rui de (ed.) - op. cit., t. I, respetivamente). Note-se que, para além da robora do rei e do infante seu filho, o diploma é também roborado pelo conde D. Henrique ("Comes dominus Enrricus, confirmat et roborat"), enquanto o conde D. Raimundo aparece como simples confirmante ("Comes Raymundus, conf.").

${ }^{44}$ GAMBRA, Andrès - op. cit., II, doc. 188: "Roborata uero in Castro de Monzon".

${ }^{45}$ GAMBRA, Andrès - op. cit., II, doc. 189: "quando rex de Burgis egressus, cum sola castellanorum expedicione".

${ }^{46}$ Não conseguimos determinar com segurança se o «pacto sucessório» procurou antecipar ou se se seguiu a esta nomeação formal de D. Sancho como sucessor ao reino de Leão e Castela. Não se pode descartar a possibilidade de que este facto, associado a uma crescente importância política do conde D. Henrique, derivada da sua presença continuada na corte (como se pode depreender do documento referido na nota $\mathrm{n}^{\circ} 43$ ), possa estar na origem de uma reação tardia do conde D. Raimundo, que o levaria a incorrer numa traição ao rei Afonso VI quando considerou que já não havia outra saída. Neste caso, poderíamos encaixar o pacto entre maio e setembro de 1107, mês em que veio a falecer Raimundo. Seja como for, o que é relevante constatar é que os condes acordaram entre si não perturbar o status quo, deixando tacitamente a resolução do conflito para depois da morte de Afonso VI, como se depreende do compromisso assumido por ambos no texto do pacto: "Iuro etiam quod post obitum Regis IL[defonsi]" (ESTEFÂNIO, Abel - "Proposta de aclaração do 'pacto sucessório' à luz de novos dados". Medievalista [Em linha]. No 16 (Julho-Dezembro 2014, p. 28).

${ }^{47}$ HERRERO DE LA FUENTE, Marta (ed.) - op. cit., docs. 1153, 1154, 1156 e 1157, respetivamente.

${ }^{48}$ SALAZAR Y ACHA, Jaime de - "Contribuición al estudio del reinado de Alfonso VI de Castilla: Algunas aclaraciones sobre su política matrimonial". in Anales de la Real Academia Matritense de Heráldica y Genealogía. Madrid. 2 (1992-93), p. 228.

${ }^{49}$ Uma notícia obituária da Abadia de Saint-Bénigne de Dijon regista a morte do conde Raimundo no dia 20 de setembro de 1107 (conforme AMARAL, Luís Carlos e BARROCA, Mário Jorge - op. cit., p. 50). Segundo a História Compostelana "el católico rey don alfonso, quien había venido para verle en sua enfermidad, ya que le distinguia com el privilegio de un afecto especial" (tradução em castelhano de FALQUE REY, Emma (ed.) - Historia Compostelana. Madrid: Ediciones Akal, 1994, p. 122). Uma opinião contrária sobre a natureza da relação entre o rei Afonso VI e o conde D. Raimundo é apresentada pelo arcebispo de Toledo Rodrigo Jiménez de Rada, em De Rebus Hispaniae, assinalando sobre o rei Afonso VI "que Raimundo de Borgoña nunca le había agradado" (tradução do latim de RODRÍGUEZ LÓPEZ, Ana - "Sucesión regia y legitimidad política en Castilla en los siglos XII y XIII. Algunas consideraciones sobre el relato de las crónicas latinas castellano-leonesas". in ALFONSO, Isabel, ESCALONA, Julio y MARTIN, Georges (eds.) - Lucha política: condena y legitimación en las

Medievalísta online $N^{\circ} 19 \mid$ Janeiro - Junho 2016 (C) IEM - Instituto de Estudos Medievais 13 
alterações no equilíbrio político do reino ${ }^{50}$. Nos primeiros meses de 1108 o rei Afonso VI contraiu um novo matrimónio, apesar de se encontrar enfermo da doença que o havia de conduzir à morte ${ }^{51}$. Estas mudanças devem ter levado o conde D. Henrique a permanecer junto da corte, o que é corroborado pelo facto de voltar a aparecer na documentação de Sahagún em 17 de fevereiro e 31 de março ${ }^{52}$.

A 29 de maio de 1108 o infante Sancho encontra a morte no decurso da batalha de Uclés $^{53}$. O desaparecimento do herdeiro oficial ao trono abriria novas perspetivas que D. Henrique não deixaria de abordar. Apesar de neste ano o conde, juntamente com D. Teresa, terem outorgado foros aos povoadores de Tentúgal e terem concedido uma carta de couto à igreja de São Martinho de Espiunca, no concelho de Arouca, não devem ter saído da corte do reino de Leão ${ }^{54}$. A evidência disso está no facto de a carta de couto estar datada de 31 de março, exatamente o mesmo dia do mês de março do documento original de Sahagún atrás referido. Apesar de D. Teresa não confirmar o documento de Sahagún, ficamos a saber pela carta de couto que estava junto do marido. Esta é uma lição que não podemos desperdiçar. A confirmação de documentos particulares parece ser uma atribuição exclusiva de D. Henrique, não significando, portanto, que D. Teresa se encontrasse ausente.

sociedades medievales. Lyon: École Normale Supérieure, 2004, p. 37). Sobre a possibilidade de ter havido um verdadeiro enfrentamento entre o monarca e o conde D. Raimundo, remontando a 1095, de que resultaria a separação da terra portucalense da Galiza e a sua entrega a D. Henrique, veja-se AMARAL, Luís Carlos e BARROCA, Mário Jorge - op. cit., pp. 116-119.

${ }^{50}$ Entre outubro e dezembro de 1107 realizou-se uma assembleia magna em Leão (GAMBRA, Andrès op. cit., I, p. 549). O rei leonês estipula que o seu neto Afonso Raimundes ficaria com a Galiza se a sua mãe voltasse a casar: "nepoti meo, proculdubio famulatures exhibeo, et totam ei Gallaetiam concedo, si ejus mater Urraca virum ducere voluerit" (FLÓREZ, Enrique (ed.) - Historia Compostellana, in España Sagrada. Madrid, 1765, vol. 20, pp. 95-96). O ato foi presenciado pelo arcebispo Guido de Vienne (em França), irmão de D. Raimundo, que em 1119 se tornaria no Papa Calixto II. É provável que ele tenha sido convocado para ajudar a proteger os interesses do seu sobrinho.

${ }^{51}$ Sobre o estado de saúde de Afonso VI e a última das suas esposas, de nome Beatriz, consulte-se GAMBRA, Andrès - op. cit., I, pp. 476-477.

${ }^{52}$ HERRERO DE LA FUENTE, Marta (ed.) - op. cit., docs. 1160 e 1162, respetivamente.

${ }^{53}$ AMARAL, Luís Carlos e BARROCA, Mário Jorge - op. cit., p. 161.

${ }^{54}$ AZEVEDO, Rui de (ed.) - op. cit., t. I, docs. 12 e 13, respetivamente. Note-se que a existência de onze documentos leoneses entre 7 de novembro de 1106 e 31 de março de 1108, inviabiliza que o conde D. Henrique pudesse ter estado em Portugal entre Agosto de 1106 e o fim de Março de 1108, como supôs o Professor José Mattoso nos itinerários que traçou do conde, certamente por não dispor então das fontes impressas leonesas por nós citadas (MATTOSO, José - História de Portugal. Vol. 2 - A monarquia feudal (1096-1480). Coordenação de José Mattoso. Lisboa: Círculo de Leitores, 2003, p. 43).

Medievalísta online No 19| Janeiro - Junho 2016 (C) IEM - Instituto de Estudos Medievais 14 
Voltamos a ter notícia do conde em 4 de setembro de 1108 a confirmar um documento particular do mosteiro de Sahagún, onde o tornamos a encontrar em 22 de maio de $1109^{55}$. Deve ter sido por esta altura que o conde D. Henrique se incompatibilizou com o seu sogro Afonso $\mathrm{VI}^{56}$, que morreu pouco tempo depois, entre 29 de junho e 1 de julho, conforme as fontes ${ }^{57}$, deixando o trono para a sua filha D. Urraca. Só a partir destes acontecimentos é que deve ter pensado em estabelecer residência no Condado Portucalense.

Afastada a veracidade da notícia veiculada pelos Annales Portucalenses Veteres de em julho de 1109 o conde D. Henrique ter recuperado o castelo de Sintra ${ }^{58}$, os primeiros documentos que nos dão conta da sua presença em Viseu e em Coimbra, juntamente com D. Teresa, são os dois referentes à doação do mosteiro de São Mamede de Lorvão à Sé de Coimbra, ambos datados de 29 de Julho de 1109, que parece ter sido objeto de

${ }^{55}$ HERRERO DE LA FUENTE, Marta (ed.) - op. cit., docs. 1163 e 1167, respetivamente.

${ }^{56}$ A Primera crónica anónima de Sahagún refere que D. Henrique, poucos dias antes de morrer Afonso VI "non se por que, entrebeniente discordia e sanna, se partió ayrado del rrei" (PUYOL Y ALONSO, Julio (ed.) - Las crónicas anónimas de Sahagún: nueva edición conforme un ms. del siglo XVI. Madrid, 1920 , p. 41). Este passo do texto tem merecido uma particular atenção dos historiadores. Desde BARRILARO RUAS, Henrique ("Se partio ayrado del rrei”. separata da Revista Portuguesa de História, tomo IV. Coimbra, 1955, pp. 5-7) tem havido algum consenso em torno de uma interpretação que considera que o conde D. Henrique foi expulso da corte com a ira de Afonso VI. Todavia, merece a pena registar aqui a interpretação recente deste passo por MONTENEGRO, Julia ("Enrique de Borgoña en la Primera crónica anónima de Sahagún”. in e-Spania [Online]. 19 I octobre 2014, posto online no dia 13 Outubro 2014, consultado em 21 Fevereiro 2015. URL : http://e-spania.revues.org/23881; DOI: 10.4000/e-spania.23881, parágrafo 3) que relança a discussão do assunto: "Se ha venido interpretando que el magnate borgoñón había incurrido en la ira regia. Creo, sin embargo, que lo que dice el cronista es sencillamente que don Enrique abandonó la corte enfadado con el rey; razones no le faltaban para ello".

${ }^{57}$ Para uma análise das diferentes fontes sobre a data em que morreu Afonso VI, consultar VIDAL ENCINAS, Julio M. e PRADA MARCOS, María Encina - "El monasterio y panteón de Alfonso VI en Sahagún: Aspectos históricos y arqueo-antropológicos”. in ESTEPA DIEZ, Carlos, FERNÁNDEZ GONZÁLEZ, Etelvina e RIVERA BLANCO, Javier (ed.) - Congreso internacional 'Alfonso VI y su legado’. León: Diputación Provincial de León / Instituto Leonés de Cultura, 2012, pp. 243-244.

58 DAVID, Pierre (ed.) - Annales Portucalenses Veteres. in Études Historiques sur la Galice et le Portugal du VI au XII siècle. Lisboa-Paris: Livraria Portugália Editora, Société d'Édition Les Belles Lettres, 1947, p. 301: "Era 1147 mense iulio item capta fuit Sintria a comite D. Henrico genero Domni Alphonsi regis marito filie sue regine D. Tarasie; audientes enim Sarraceni mortem regis D. Alphonsi ceperunt rebellare". Este texto deve ter sido mal transcrito ou mal datado, de acordo com a opinião expressa por MATTOSO, José (D. Afonso Henriques. Lisboa: Temas e Debates, 2007, p. 32, nota 1). Segundo a Saga de Sigurd, o Cruzado, e de seus irmãos Eystein e Olaf, o castelo de Sintra foi conquistado pelos noruegueses aos muçulmanos em 1109, podendo o conde D. Henrique ter recebido o senhorio da vila, sem que tal implicasse a sua presença física na região (conforme BARROCA, Mário Jorge - "Da Reconquista a D. Dinis". in MATTOSO, José (coord) - Nova história militar de Portugal. Vol. 1. Lisboa: Círculo de Leitores, 2003, pp. 35-36). No mesmo ano, os defensores do castelo de Sintra revoltar-se-iam contra o domínio do conde D. Henrique, colocando-se do lado dos almorávidas que dominavam Lisboa.

Medievalísta online No 19| Janeiro - Junho 2016 (C) IEM - Instituto de Estudos Medievais 15 
cerimónias próprias nas duas cidades ${ }^{59}$. Estes documentos levantam duas questões que até aqui ainda não foram convenientemente tratadas. A primeira diz respeito à necessidade de realização de uma cerimónia extra em Viseu, quando o que seria mais razoável de admitir era ter-se realizado um único ato solene super altare na catedral de Coimbra. A segunda relaciona-se com a necessidade de estabelecer uma sequência lógica entre os dois atos. Dada a impossibilidade física, à época, de se terem realizado as duas cerimónias no mesmo dia, atendendo a que as duas cidades se encontram separadas por $90 \mathrm{~km}$, o segundo ato adviria da necessidade de confirmação posterior do primeiro, em data possivelmente próxima, mas que se desconhece.

De acordo com a tese formulada por Almeida Fernandes, a primeira cerimónia da outorga foi efetuada em Coimbra e a segunda em Viseu. A razão que apresenta para a segunda cerimónia, justifica-a pela necessidade de D. Teresa confirmar o ato, admitindo que o não poderia ter feito em Coimbra porque estaria impedida fisicamente em Viseu, por motivo do nascimento de seu filho Afonso Henriques, em agosto desse ano ${ }^{60}$. Esta asserção não tem suporte documental, dado que ela confirma o diploma de Coimbra do mesmo modo que o de Viseu. Também não é de crer que D. Teresa empreendesse a viagem do reino de Leão para Viseu, caso estivesse no final de uma gravidez. Note-se bem que não existe qualquer documento anterior a essa data que comprove a sua presença na cidade e nenhuma importância tem, para o efeito, toda a documentação que se possa aduzir para comprovar a sua presença nos anos que se seguiram.

Por outro lado, Almeida Fernandes não chegou a ter conhecimento de um documento essencial para se estabelecer um correto encadeamento dos factos e que torna inverosímil que a primeira cerimónia se tivesse realizado em Coimbra. Trata-se do primeiro diploma de D. Urraca que conhecemos na qualidade de rainha, em que faz

${ }^{59}$ RODRIGUES, Manuel Augusto; COSTA, Avelino de Jesus da; VELOSO, Maria Teresa Nobre (eds.) Livro Preto, cartulário da Sé de Coimbra. Coimbra: Arquivo da Universidade de Coimbra, 1999, doc. 59 e AZEVEDO, Rui de (ed.) - op. cit., t. I, doc. 15, sendo a primeira referência relativa à outorga realizada em Viseu e a segunda à outorga realizada em Coimbra.

${ }^{60}$ A tese do local de nascimento em Viseu desenvolve-se em torno da consideração demasiado simplista de uma "única fonte da idade de D. Afonso Henriques - dois para três anos, quando o pai morreu, o que sucedeu de Abril para Maio de 1112" (FERNANDES, A. de Almeida - Viseu, Agosto de 1109, nasce D. Afonso Henriques. Viseu: SACRE/Fundação Mariana Seixas, 2007, p. 10), não procedendo, portanto, a qualquer avaliação crítica comparativa com as outras fontes, o que se justificaria por serem contraditórias entre si.

Medievalista online № 19| Janeiro - Junho 2016 @ IEM - Instituto de Estudos Medievais 16 www2.fcsh.unl.pt/iem/medievalista 
doação de várias possessões e concede liberdades e privilégios à Sé de Leão, datado de 22 de julho de $1109^{61}$, um dia depois do funeral de seu pai Afonso VI realizado em Sahagún $^{62}$. Nele confirma o arcebispo de Toledo D. Bernardo e o conde D. Pedro Froilaz. Se este conde galego se volta a encontrar a confirmar os diplomas de Viseu e de Coimbra, o arcebispo de Toledo só nos aparece a confirmar o diploma de Viseu. O que os documentos sugerem é que de Sahagún vieram as duas personalidades a Viseu ${ }^{63}$. O facto de D. Bernardo não ter prosseguido para Coimbra, por razões que nos escapam, teria levado a que a outorga da doação do mosteiro de Lorvão à Sé de Coimbra se realizasse em Viseu. Desta cidade partiriam para Coimbra o conde D. Henrique, D. Teresa, o conde D. Pedro Froilaz e um grande número das testemunhas da cerimónia de Viseu, para a realização de uma segunda cerimónia na Sé beneficiária ${ }^{64}$.

${ }^{61}$ RUIZ ALBI, Irene - La reina doña Urraca (1109-1126). Cancillería y colección diplomática. León: Centro de Estudios e Investigación «San Isidoro» / Caja España de Inversiones / Archivo Histórico Diocesano, 2003, doc. 1: "ego, Urraka, Dei nutu totius Yspanie Regina".

${ }^{62}$ SALVADOR MARTINEZ, H. ("Emperador de sueños", in ESTEPA DIEZ, Carlos, FERNÁNDEZ GONZÁLEZ, Etelvina e RIVERA BLANCO, Javier (ed.) - Congreso internacional 'Alfonso VI y su legado'. León: Diputacion Provincial de León / Instituto Leonês de Cultura, 2012, p. 135, nota 17) constata que segundo a Crónica de don Pelayo o enterro teve lugar em 21 de julho e que o Anónimo I de Sahagún refere o dia 12 de agosto ("duodécimo día de agosto"), optando por preferir esta última data, por admitir que o monge do mosteiro de Sahagún onde Afonso VI foi sepultado e testemunha ocular dos acontecimentos estaria melhor informado. Não nos devemos esquecer, contudo, que só conhecemos o seu texto por uma versão tardia em língua castelhana. Admito que possa ter havido uma deficiente transmissão da data e que no original latino perdido estivesse "XII kalendas augusti", que não é nada mais nada menos que o dia 21 de julho registado por D. Paio de Oviedo. Se o Autor Anónimo tivesse pretendido indicar o dia 12 de agosto teria utilizado "II idus augusti", em consonância com o que fez para indicar o dia 9 de julho em que o corpo de Afonso VI foi levado de Toledo para Sahagún, onde deve ter mencionado "VII idus iulii" ("sétimo de los idus de julio" na versão castelhana que conhecemos).

${ }^{63} \mathrm{O}$ trajeto de Sahagún para Viseu, passando por Leão, Astorga, Bragança, Alfândega da Fé, Penedono, Sernancelhe e Sátão, totaliza cerca de $434 \mathrm{~km}$ (cálculo efetuado com a ajuda do Google Maps, para um percurso a pé, em que nos baseamos, com algumas alterações de pormenor, no trajeto mais rápido entre Viseu e a capital do reino leonês, proposto por REAL, Manuel ("Mosteiro de Fráguas no contexto do préromânico da Beira Interior (Portugal)". in Muçulmanos e Cristãos entre o Tejo e o Douro (Sécs. VIII a XIII). Palmela: Câmara Municipal de Palmela / Faculdade de Letras da Universidade do Porto, 2005, p. 278). Como entre o documento de Sahagún e o de Viseu decorreram sete dias, implica uma média diária de $62 \mathrm{~km}$. Num percurso alternativo desde Sahagún, passando por Zamora, Miranda do Douro, Torre de Moncorvo e entroncando no percurso definido anteriormente em Sernancelhe com destino a Viseu, rondaria os $384 \mathrm{~km}$, de que resultaria uma progressão média diária de $55 \mathrm{Km}$. Nos mesmos sete dias, refere o cronista árabe Ibn Al-Sabbat ser o tempo necessário para percorrer os $320 \mathrm{~km}$ que separam Toledo de Córdova, à razão de $46 \mathrm{~km}$ diários. Os mesmos dias que são necessários para ir de Toledo a León, segundo o geografo árabe Al-Idrisi, separadas entre si por quase $400 \mathrm{~km}$, o que estabelece etapas de quase $57 \mathrm{~km}$ diários (conforme VIDAL ENCINAS, Julio M. e PRADA MARCOS, M ${ }^{\mathrm{a}}$ Encina - op. cit., p. 246).

${ }^{64}$ Creio que deste modo é possível justificar o motivo da comparência das testemunhas de Viseu na validação do documento de Coimbra, que tinha deixado perplexo AZEVEDO, Rui de (ed.) - op. cit., t. I, p. XLIII.

Medievalísta online $\mathrm{N}^{\circ}$ 19| Janeiro - Junho 2016 @ IEM - Instituto de Estudos Medievais 17 www2.fcsh.unl.pt/iem/medievalista 
Não podemos deixar de considerar a dupla cerimónia da doação do mosteiro de Lorvão à Sé de Coimbra como um passo político muito significativo em direção à autonomia de Portugal. Desde logo pela presença do primaz toledano em Viseu, que discordaria do planeado matrimónio que se realizaria ainda nesse ano de 1109 entre D. Urraca e Afonso I de Aragão, o Batalhador ${ }^{65}$. Mas também pela comparência do poderoso e influentíssimo conde de Trava, que tinha sido um dos principais vassalos do conde D. Raimundo $^{66}$. As duas personalidades davam assim um contributo forte para a secessão de facto de «Portugal» sob o domínio do conde D. Henrique ${ }^{67}$ que se intitula agora de "Dei gratia comes et totius Portugalensie dominus" 68.

${ }^{65}$ A Historia Compostelana refere que, em consequência, D. Bernardo foi expulso da Sé de Toledo pelo rei de Aragão pelo espaço de dois anos (Archiepiscopum ... per biennium absentavit) (conforme HERCULANO, Alexandre - História de Portugal desde o começo da monarquia até ao fim do reinado de Afonso III. Prefácio e notas críticas de José Mattoso. Tomo I. Lisboa: Bertrand, 1989, p. 631 e FLÓREZ, Henrique (ed.) - Historia Compostellana, op. cit., p. 116).

${ }^{66}$ Embora o conde Pedro Froilaz tenha sido criado na corte de Afonso VI, tinha lá uma posição secundária, o que pode ter constituído um fator determinante para o levar a situar-se na dependência do conde D. Raimundo. A sua presença continuada como confirmante de diplomas do conde borgonhês entre 1095 e 1107 põe de manifesto a sua fidelidade, o que não deixou de lhe proporcionar vantagens significativas, tornando-se um grande proprietário de terras da Galiza (conforme BARÓN FARALDO, Andrés - "Magnates y "nobiles" en la curia del conde Raimundo de Borgoña. "Totius gallecie princeps" (ca. 1091-1107)". in Estudios mindonienses: Anuario de estudios histórico-teológicos de la diócesis de Mondoñedo-Ferrol, 27 (2001), pp. 531-574). Sabemos também que foi encarregado de educar Afonso Raimundes e que a sua instância e do prelado compostelano Diogo Gelmires o infante foi coroado rei na catedral de Santiago de Compostela, no dia 17 de setembro de 1111 (AMARAL, Luís Carlos e BARROCA, Mário Jorge - op. cit., pp. 68 e 165). Não nos parece impossível que o conde de Trava tivesse conhecimento dos termos do «pacto sucessório», no qual Raimundo admitia a possibilidade de entregar a Galiza a Henrique em troca do seu apoio na sucessão ao reino de Leão e Castela e que, pela morte dos dois signatários, assumisse o papel de fiel executor do pacto, defendendo os direitos do infante ao trono, o que o levou em determinadas ocasiões a guerrear D. Urraca. Assim se poderá compreender melhor que tenha apoiado D. Teresa na reconstrução do reino da Galiza a partir de 1117, ao mesmo tempo que procurou retirar vantagens pessoais pela integração dos seus filhos na linhagem condal, e tenha prestado obediência a Afonso VII depois da sua aclamação como rei de Leão e Castela, em fins de março de 1126, na sequência da morte da mãe (Ibidem, pp. 68 e 221-223).

${ }^{67}$ Sigo a opinião expressa por FLETCHER, Richard A. - The Episcopate in the Kingdom of León in the Twelfth Century. Oxford: Oxford University Press, 1978, p. 16.

${ }^{68}$ Note-se que esta intitulação, assim como o grosso do texto do documento, teve por modelo a escritura de doação do Mosteiro de São Vicente da Vacariça à Sé de Coimbra, realizada pelo conde D. Raimundo e sua mulher, a infanta D. Urraca, em 13 de novembro de 1094, que foi elaborada pelo então notário e posteriormente arcebispo de Santiago de Compostela Diogo Gelmires (Portugaliae Monumenta Historica, Diplomata et Chartae. Lisboa: Academia das Ciências de Lisboa, 1873, vol. I, doc. 813). Ao fazer uso das mesmas expressões, o conde D. Henrique procuraria mimetizar o mesmo poder de que o seu falecido primo se tinha investido.

Medievalísta online No 19| Janeiro - Junho 2016 (C) IEM - Instituto de Estudos Medievais 18 www2.fcsh.unl.pt/iem/medievalista 
Se "a primeira tarde portuguesa" se realizou em S. Mamede ${ }^{69}$, assistimos "aos primeiros raios da aurora desse dia" em Viseu e Coimbra. Entre esses dois importantes marcos é de assinar o facto de D. Teresa abandonar, em 1117, o título de "infanta" e passar a intitular-se "rainha" entre outros momentos significativos, a aclamação de Afonso Henriques como rei em $1139^{71}$, e terminaria, já «noite fora», com o que podemos considerar como uma autêntica «certidão de nascimento» do novo reino, por meio da bula Manifestis probatum est ${ }^{72}$.

Nos três escassos anos que medeiam entre a doação do mosteiro de Lorvão à Sé de Coimbra até à sua morte em 24 de abril de 1112, o conde D. Henrique e D. Teresa outorgaram um significativo de diplomas condais que chegaram até nós. Temos registo de oito cartas de couto e doações, sendo quatro concedidas à Sé de Braga e as restantes ao mosteiro de Tibães, à Sé de Viseu, a Fromarigo Guterres de propriedades em Guimarães e Esposende e a Bernardo Barcelona em Sátão ${ }^{73}$. Entre maio e junho de 1111, outorgam os forais de Sátão, Coimbra e Soure ${ }^{74}$. Deve ser do mesmo período o foral de Azurara da Beira ${ }^{75}$. No entanto, entre 1110 e 1111 , os condes devem ter-se

${ }^{69}$ A sugestiva expressão foi adotada por MATTOSO, José - "A primeira tarde portuguesa". in Revista de Guimarães, 88 (1978), pp. 159-186.

${ }^{70}$ Sobre o contexto histórico em que D. Teresa começou a utilizar o título de rainha, consulte-se AMARAL, Luís Carlos e BARROCA, Mário Jorge - op. cit., pp. 193-194.

${ }^{71}$ Sobre a aclamação de Afonso Henriques, veja-se MATTOSO, José - D. Afonso Henriques, pp. 167170.

${ }^{72}$ Em 23 de maio de 1179 o papa Alexandre III reconheceu Afonso Henriques como rei (Ibidem, pp. 359362).

${ }^{73}$ AZEVEDO, Rui de (ed.) - op. cit., t. I, tendo os docs. 16 (10 de dezembro de 1109?), 22 (29 de outubro de 1110 (?)) e 23 (9 de novembro de 1110 (?)) e 30 (12 de abril de 1112) como destinatário a Sé de Braga e os docs. 17 (25 de março de 1110), 19 (21 de julho de 1110), 20 (24 de julho de 1110), 21 (agosto de 1110) os outros destinatários acima nomeados, respetivamente. Atente-se, todavia, que os docs. 20, 22 e 23 foram outorgados apenas por D. Teresa. De acordo com AMARAL, Luís Carlos e BARROCA, Mário Jorge (op. cit., p. 43), o conde D. Henrique participou, em 24 de janeiro de 1110, na Batalha de Valtierra (junto a Tudela) ao lado do exército de Afonso I de Aragão, em que foi derrotado o rei da taifa de Saragoça, al-Mustain I. Tendo regressado ao Condado Portucalense em março, ausentar-se-ia novamente em julho do mesmo ano. Em outubro surgiria ao lado de Afonso I de Aragão na Batalha de Candespina (Segóvia, 26 de outubro de 1110), na qual alcançaram uma significativa vitória sobre D. Urraca (Ibidem, p. 149).

${ }^{74}$ AZEVEDO, Rui de (ed.) - op. cit., t. I, docs. 24 (9 de maio de 1111), 25 (26 de maio de 1111) e 26 (junho de 1111).

${ }^{75}$ Ibidem, doc. 14 ([1109-1112]). Note-se que Almeida Fernandes presumiu que o foral de Azurara foi concedido a 5 de agosto de 1109, o mesmo dia em que considerou ter nascido Afonso Henriques em Viseu. Seria esse o motivo do impedimento do conde D. Henrique e de D. Teresa que, por um hipotético compromisso que não poderia ser adiado, os teria levado a enviar, em sua substituição, uma delegação a

Medievalísta online $N^{\circ} 19 \mid$ Janeiro - Junho 2016 (C) IEM - Instituto de Estudos Medievais 19

www2.fcsh.unl.pt/iem/medievalista 
ausentado do condado, tendo então concedido a foral de Oca, na província de Burgos ${ }^{76}$. Também o foral de Tavares ${ }^{77}$ deve ter sido produzido fora do Condado Portucalense, possivelmente em Astorga ou Leão, dado que apenas três dias depois encontramos os condes a fazer uma doação de bens em Astorga e, um mês depois, outra em Oviedo, ambas com a presença da rainha D. Urraca ${ }^{78}$. É ainda atestada, por um documento particular, a presença do conde D. Henrique em Sahagún no dia 15 de dezembro de $1110^{79} \mathrm{e}$, por um outro, no dia de Natal em Coimbra ${ }^{80}$, para o reencontrarmos treze dias depois a confirmar uma doação da rainha D. Urraca à igreja de Valhadolid ${ }^{81}$.

Estes dados levam-nos a acompanhar a conclusão de Henrique Barrilaro Ruas ${ }^{82}$, de estarmos perante uma apertada cronologia que parece ultrapassar, algumas vezes, as possibilidades físicas e políticas que colocam o conde, ora no Condado, ora fora, ao lado de um ou do outro cônjuge do casamento desavindo entre D. Urraca e Afonso I de Aragão, o que mereceria um estudo mais aprofundado.

Mangualde para a sua concessão (FERNANDES, A. de Almeida - op. cit., p. 128). Ora, como os dois acontecimentos são de data incerta, um não serve para validar o outro. Num estudo que vai ser publicado brevemente na Revista Beira Alta, avalio a possibilidade de o foral de Azurara ter sido concedido pouco tempo depois do foral do Sátão, outorgado a 9 de Maio de 1111. O bispo de Coimbra, Gonçalo Pais, que foi confirmante no foral do Sátão, não se encontra na lista dos confirmantes do foral de Coimbra, outorgado a 26 de Maio de 1111, mas aparece no papel de notário do foral de Azurara. Admito que a revolta da comunidade moçárabe de Coimbra possa ter justificado que essa função tenha sido executada excecionalmente por um bispo, que assim era afastado do centro da discórdia em que estava envolvido. $\mathrm{O}$ conde D. Henrique seguiria diretamente para Coimbra para apaziguar os ânimos exaltados na cidade, enquanto uma delegação sua receberia o juramento de fidelidade dos moradores de Azurara. No mês seguinte, o bispo e dois magnates que o tinham acompanhado a Azurara estão novamente com o conde na outorga do foral a Soure. Deste modo, é possível que o foral de Azurara tenha sido outorgado entre maio e junho de 1111 (conforme ESTEFÂNIO, Abel - "Os Forais condais de Mangualde e os seus problemas de datação cronológica". in Revista Beira Alta, 74 (2015), no prelo).

${ }^{76}$ AZEVEDO, Rui de (ed.) - op. cit., t. II, doc. 16bis ([1110, 1111]).

77 AZEVEDO, Rui de (ed.) - op. cit., t. I, doc. 27 (27 de fevereiro de [1112]). Numa reavaliação posterior, o diplomatista alterou a data crítica do foral de Tavares para [1111,1112], excluindo justamente o dia 27 de fevereiro de 1112, por ter constatado que, de acordo com o doc. 28, o conde D. Henrique estava em Astorga a 1 de março de 1112 (AZEVEDO, Rui de (ed.) - op. cit., t. II, nota VIII, pp. 568569).

${ }^{78}$ Ibidem, docs. 28 ( 1 de março de 1112) e 29 (27 de março de 1112), respetivamente.

79 ESCALONA, Romualdo - Historia del Real Monasterio de Sahagún. Madrid, 1782, p. 509 e FERNÁNDEZ FLÓREZ, José Antonio (ed.) - Coleccion Diplomática del Monasterio de Sahagún (8571230), T. IV (1110-1199). León: Centro de Estudios e Investigación «San Isidoro» (CSIC-CECEL), Caja España de Inversiones, Archivo Histórico Diocesano, 1991, doc. 1180.

80 AZEVEDO, Rui de (ed.) - Documentos Medievais Portugueses, Documentos Particulares. Vol. III - AD. 1101-1115. Lisboa: Academia Portuguesa de História, Lisboa, 1940, doc. 369 (25 de dezembro de 1110).

${ }^{81}$ RUIZ ALBI, Irene - op. cit., doc. 18 (7 de janeiro de 1111).

82 BARRILARO RUAS, H. - "Henrique, conde D.". in SERRÃO, Joel (dir.) - Dicionário da História de Portugal. Vol. III. Porto: Livraria Figueirinha, 1971, p. 195.

Medievalísta online $N^{\circ} 19 \mid$ Janeiro - Junho 2016 (C) IEM - Instituto de Estudos Medievais 20 
Vistas as coisas do modo como nos permitem as fontes documentais, se Afonso Henriques tivesse nascido depois de julho de 1109, como é indicado por algumas fontes, seria possível que tivesse nascido em Coimbra ${ }^{83}$, mas também não vejo como poderíamos rejeitar liminarmente que tivesse nascido em Guimarães ou Viseu. A documentação desse período permite supor a permanência ou pelo menos a passagem de D. Teresa por essas cidades.

\section{Uma nova proposta do local de nascimento de Afonso I}

Estamos agora em condições para nos concentrarmos nos anos em torno de 1106 que, de acordo com as fontes por nós acima citadas, consideramos como sendo o ano mais provável do nascimento de Afonso Henriques. A documentação do mosteiro de Sahagún revelou-se determinante para verificamos a presença continuada do conde D. Henrique e de D. Teresa junto da corte do reino de Leão e Castela. Às doze confirmações de diplomas de Sahagún, que tínhamos registado no período entre 1098 e 1103, verificamos depois a participação do conde D. Henrique em vinte e oito documentos da mesma coleção documental, no período entre 1104 e 1109, fornecendonos, afortunadamente, uma malha mais apertada para a localização do conde.

Quando confrontamos os dois documentos condais de 1106, assim como os outros dois de 1108, com a documentação do mosteiro de Sahagún, de datas próximas dessas, chegamos à conclusão que não podiam ter estado no Condado Portucalense, mesmo que pontualmente, para a sua outorga.

\footnotetext{
${ }^{83}$ Para além das fontes documentais, a presença de D. Teresa em Coimbra é ainda atestada pela Primeira crónica anónima de Sahagún, após a batalha de Candespina que ocorreu perto de Sepúlveda, no dia 26 de Outubro de 1110: "E estando nisto, D. Teresa, mulher do conde Henrique, filha do rei D. Afonso [VI], que tinha ficado em Coimbra, veio ter com ele" (conforme tradução para português recolhida em AMARAL, Luís Carlos e BARROCA, Mário Jorge - op. cit., pp. 317-318). Note-se que SOARES, Torquato de Sousa (“Afonso I, D.”, in SERRÃO, Joel (dir.) - Dicionário de História de Portugal. Vol. I. Lisboa: Iniciativas Editoriais, 1975, p. 36) considerou, todavia, o nascimento de D. Afonso Henriques na alcáçova de Coimbra em finais de 1108 ou num dos primeiros meses de 1109, o que carece de suporte documental, quer quanto ao ano, quer quanto ao local. A sua proposta baseia-se apenas no facto de considerar Coimbra como o centro urbano mais importante do Condado Portucalense.
} 
Quadro resumo do itinerário do conde D. Henrique e D. Teresa entre julho de 1103 e julho de 1109

\begin{tabular}{|c|c|c|c|c|c|c|c|}
\hline \multicolumn{3}{|c|}{ Data } & \multicolumn{2}{|c|}{$\begin{array}{c}\text { Qualidade do } \\
\text { interveniente }^{84}\end{array}$} & \multirow{2}{*}{$\begin{array}{c}\text { Localidade } \\
\text { de } \\
\text { contexto }^{85}\end{array}$} & \multirow{2}{*}{$\begin{array}{c}\text { Reino onde foi } \\
\text { outorgado }^{86}\end{array}$} & \multirow[b]{2}{*}{ Fonte } \\
\hline Ano & Mês & Dia & D. Henrique & D. Teresa & & & \\
\hline \multirow[t]{3}{*}{1103} & 7 & 11 & Beneficiário & Beneficiário & Guimarães & Condado Portucalense & Azevedo (1940), doc.125 \\
\hline & 10 & - & Confirmante & Confirmante & Oviedo & Leão e Castela & Reilly (1988), p. 317 \\
\hline & 11 & 7 & Confirmante & - & Palença & Leão e Castela & Reilly (1988), p. 317 \\
\hline \multirow[t]{5}{*}{1104} & 2 & 9 & Confirmante & - & Sahagún & Leão e Castela & Herrero (1988), doc. 1101 \\
\hline & 3 & 4 & Confirmante & - & Sahagún & Leão e Castela & Herrero (1988), doc. 1102 \\
\hline & 5 & 9 & Confirmante & - & Sahagún & Leão e Castela & Herrero (1988), doc. 1105 \\
\hline & 6 & 13 & Confirmante & - & Sahagún & Leão e Castela & Herrero (1988), doc. 1108 \\
\hline & 9 & 13 & Confirmante & - & Sahagún & Leão e Castela & Herrero (1988), doc. 1114 \\
\hline \multirow[t]{7}{*}{1105} & 1 & 30 & Outorgante & Outorgante & Dueñas & Leão e Castela & Bishko (1971), p. 158 \\
\hline & \multirow[t]{2}{*}{6} & 1 & Confirmante & - & Sahagún & Leão e Castela & Herrero (1988), doc. 1123 \\
\hline & & 2 & Confirmante & - & Sahagún & Leão e Castela & Herrero (1988), doc. 1124 \\
\hline & \multirow[t]{2}{*}{9} & 11 & Confirmante & - & Sahagún & Leão e Castela & Herrero (1988), doc. 1127 \\
\hline & & 22 & Confirmante & Confirmante & Burgos & Leão e Castela & Gambra (1988), doc. 184 \\
\hline & \multirow[t]{2}{*}{12} & \multirow[t]{2}{*}{13} & Confirmante & - & Sahagún & Leão e Castela & Herrero (1988), doc. 1128 \\
\hline & & & Confirmante & - & Sahagún & Leão e Castela & Herrero (1988), doc. 1129 \\
\hline \multirow[t]{12}{*}{1106} & \multirow[t]{4}{*}{1} & 10 & Confirmante & - & Sahagún & Leão e Castela & Herrero (1988), doc. 1132 \\
\hline & & 12 & Confirmante & - & Sahagún & Leão e Castela & Herrero (1988), doc. 1133 \\
\hline & & 16 & Confirmante & - & Sahagún & Leão e Castela & Herrero (1988), doc. 1134 \\
\hline & & 22 & Confirmante & - & Sahagún & Leão e Castela & Herrero (1988), doc. 1135 \\
\hline & 2 & 19 & Confirmante & - & Sahagún & Leão e Castela & Herrero (1988), doc. 1137 \\
\hline & \multirow[t]{2}{*}{3} & 4 & Confirmante & - & Sahagún & Leão e Castela & Herrero (1988), doc. 1139 \\
\hline & & 15 & Confirmante & Confirmante & Oviedo & Leão e Castela & Gambra (1988), doc. 185 \\
\hline & 6 & 10 & Confirmante & - & Sahagún & Leão e Castela & Herrero (1988), doc. 1145 \\
\hline & 7 & 28 & Confirmante & - & Sahagún & Leão e Castela & Herrero (1988), doc. 1146 \\
\hline & \multirow[t]{2}{*}{8} & 1 & Outorgante & Outorgante & Seia & [Leão e Castela] & Azevedo (1958), doc. 10 \\
\hline & & 25 & Outorgante & Outorgante & Lorvão & [Leão e Castela] & Azevedo (1958), doc. 11 \\
\hline & 11 & 7 & Confirmante & - & Sahagún & Leão e Castela & Herrero (1988), doc. 1149 \\
\hline \multirow[t]{3}{*}{1107} & 1 & 18 & Confirmante & - & Sahagún & Leão e Castela & Herrero (1988), doc. 1150 \\
\hline & 4 & 14 & Outorgante & - & Astorga & Leão e Castela & Cavero (1999), doc. 534 \\
\hline & 5 & 8 & Confirmante & Confirmante & Monzón & Leão e Castela & Gambra (1988), doc. 188 \\
\hline
\end{tabular}

\footnotetext{
${ }^{84}$ Não foram incluídos nesta análise os documentos em que o conde D. Henrique aparece apenas referido, por não acrescentarem qualquer valor para o estudo do seu itinerário.

${ }^{85}$ A localidade de contexto dos documentos foi atribuída tendo em atenção o espaço geográfico nomeado no texto e a coleção onde se encontram inseridos.

${ }^{86} \mathrm{O}$ reino de outorga dos documentos é atribuído com elevado grau de probabilidade, se não mesmo certeza, atendendo à localidade de contexto. Excetuam-se os quatro documentos condais em que, pela proximidade temporal com documentos leoneses, nos parece improvável ou mesmo impossível que tivessem sido outorgados no Condado Portucalense. Estes casos estão assinalados pela colocação do reino de outorga estimado entre parênteses retos.
} 


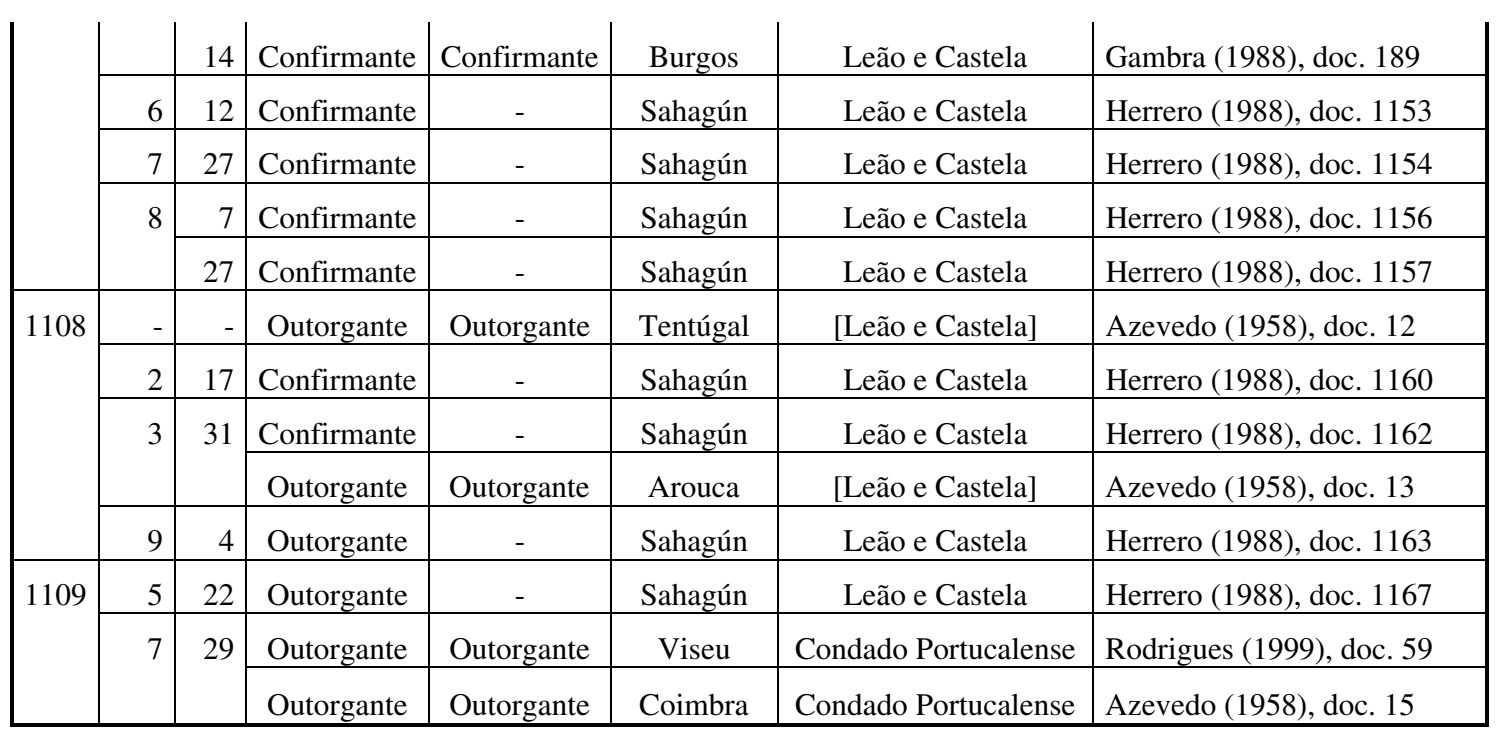

Conforme se pode constatar no Quadro acima, apesar de D. Teresa figurar somente em treze dos quarenta e três documentos listados, não existem, no período em análise, documentos outorgados ou confirmados apenas pela condessa que pudessem indiciar que se encontrasse longe do marido. Os dados parecem assim mostrar que, na sequência da sua presença no Condado Portucalense no verão de 1103, D. Teresa acompanhou o marido na viagem à corte do Reino de Leão e Castela, onde ambos devem ter permanecido até à primavera de 1109.

É neste contexto que Sahagún surge como o centro geográfico de onde o conde D. Henrique parte, com ou sem a companhia de D. Teresa, para a realização de um conjunto de atos régios entre 1103 e 1109 . Note-se que, em alguns dos casos, é possível que não tenha havido deslocação efetiva do rei Afonso VI e da sua comitiva às localidades satélites nomeadas para a produção dos documentos que lhes dizem respeito. Não excluímos, pois, a possibilidade de alguns dos atos terem sido realizados centralmente em Sahagún, tal com cremos que aconteceu com todas as confirmações de documentos particulares efetuadas pelo conde D. Henrique.

Seja como for, o que nos interessa evidenciar é que os condes se encontravam fora do Condado Portucalense. Como os quatro documentos condais que conhecemos no período entre 1106 e 1108 foram possivelmente concedidos em Sahagún, não contribuem para o traçado do itinerário dos condes portucalenses, que se apresenta no Mapa de suporte às nossas conclusões.

Medievalista online № 19| Janeiro - Junho 2016 @ IEM - Instituto de Estudos Medievais 23 www2.fcsh.unl.pt/iem/medievalista 


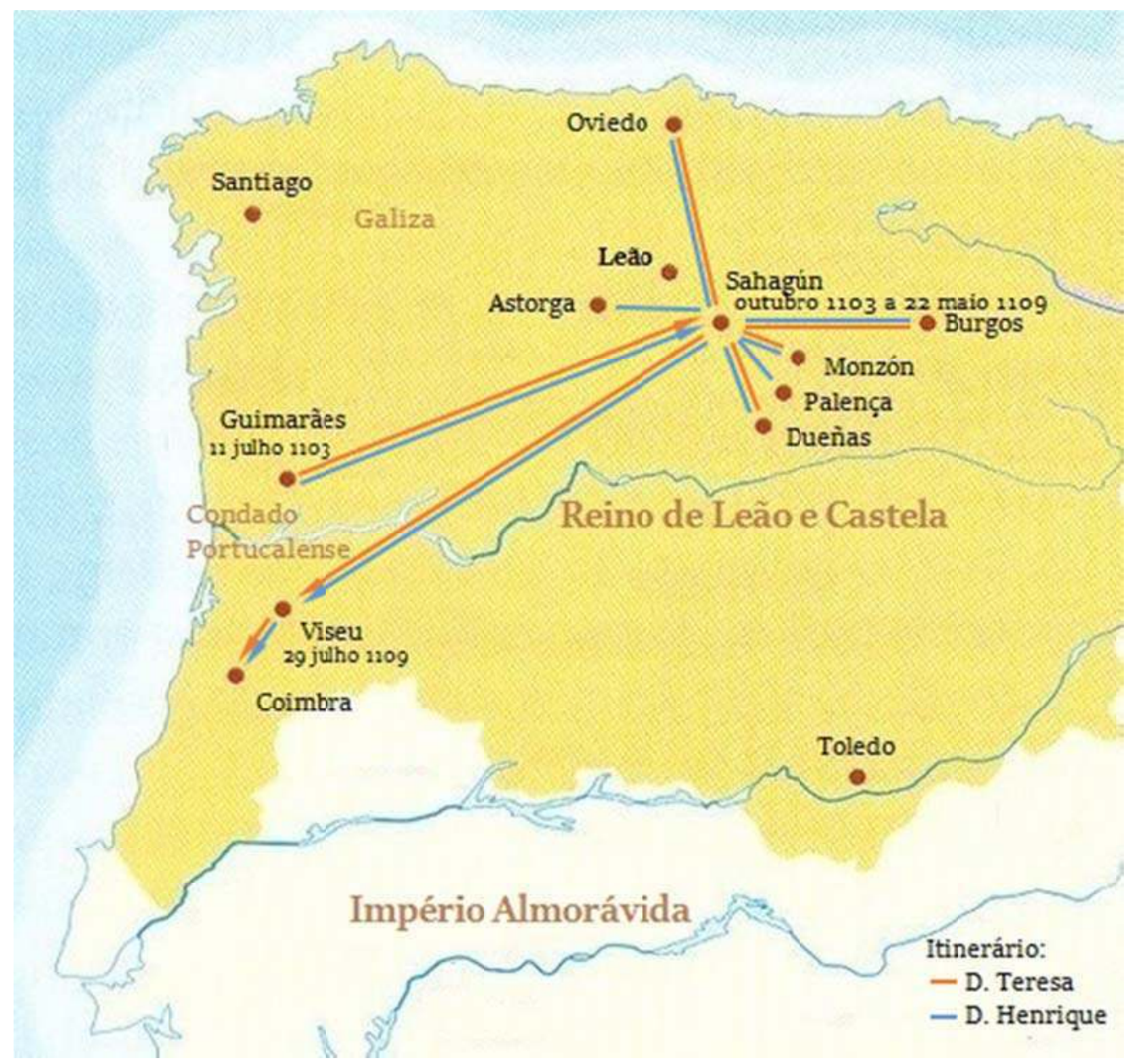

Figura 1 - Mapa síntese do itinerário do conde D. Henrique e D. Teresa entre julho de 1103 e julho de 1109

A comprovadamente longa permanência dos condes na corte de Leão não pode deixar de significar a sua grande importância política. A imagem de excelente guerreiro que sempre se reconheceu ao conde D. Henrique deve ser agora matizada pela de cortesão habituado às intrigas da corte ${ }^{87}$. Neste contexto, não me parece inocente que tenha dado ao seu filho o nome de Afonso, seguindo o exemplo do conde D. Raimundo relativamente ao seu sobrinho. Para o rei devia ser particularmente gratificante ver que os seus dois netos carregavam e perpetuavam o seu nome, mas também poderia

${ }^{87}$ Esta faceta cortesã do conde D. Henrique afasta-se da imagem tradicional que via os seus itinerários sempre relacionados com a guerra e os problemas da defesa do território, como se encontra no exposto por SOARES, Torquato de Sousa ("O governo de Conde Henrique de Borgonha". in Revista Portuguesa de História, 14 (1975), p. 375, nota 30).

Medievalísta online $N^{\circ} 19 \mid$ Janeiro - Junho 2016 ๑ IEM - Instituto de Estudos Medievais 24 
adivinhar nessa atitude a realização de um conluio entre os seus genros relativo à sucessão dos seus reinos. Algures, entre 1105 e 1107, o conde D. Henrique envolve-se em uma conspiração contra o rei Afonso VI, ao realizar o referido «pacto sucessório» com o conde D. Raimundo, sob a égide do abade Hugo de Cluny.

É notável que D. Raimundo tenha nomeado nesse documento o seu filho Afonso Raimundes, que não tinha completado três anos de idade quando o pai morreu ${ }^{88}$. Recordo que também os Annales D. Alfonsi Portugallensium Regis referem que o primo Afonso Henriques não tinha mais de três anos quando o seu pai morreu ${ }^{89}$. Sendo esta uma cronologia que, por tudo o que foi atrás escrito, não considero correta, não afasto a possibilidade de ter havido confusão na identificação do Afonso a que essa memória dizia respeito, pelo Autor Anónimo dos Anais, o que nos oferece uma explicação alternativa para o desencontro desta fonte com a Vita Theotonii, no que respeita à data de nascimento do nosso primeiro rei.

Teria também o conde D. Henrique deixado algures, para a posteridade, alguma pista da importância que um filho varão tinha para as suas aspirações sucessórias? O historiador argentino Marsilio Cassotti chamou a atenção para os qualificativos aplicados a Teresa nos dois documentos condais de $1108^{90}$. O facto de no foro de Tentúgal Henrique chamar à sua mulher "formosissima" e "dulcíssima" e na carta de couto no concelho de Arouca louvar a sua mulher chamando-lhe "gloriosa" e "dilecta" pode significar algo mais que uma mera retórica notarial. Estas expressões foram utilizadas por notários clérigos diferentes e nunca tinham aparecido em nenhum dos documentos outorgados pelos condes nem voltariam a ser usadas. É de crer que estas manifestações públicas de júbilo, usando qualificativos que encontramos associados à Virgem Maria, possam estar relacionadas com uma recente maternidade. Neste contexto, é possível que D. Teresa

88 AZEVEDO, Rui de (ed.) - Documentos Medievais Portugueses, Documentos Régios, t. I, doc. 2: "Raimundus Comes eiusque filius". "...\& ejus filius, qui adhuc trienii tempus nequaquam expleverat" (FLÓREZ, Henrique (ed.) - Historia Compostellana, op. cit., p. 95).

${ }^{89}$ BLÖCKER-WALTER, Monica - Annales D. Alfonsi Portugallensium Regis, in Alfons I von Portugal. Studien zu Geschichte und Sage der Begrunders der portugiesichen Unbhangigkeiten. Zurich: Fretz und Wasmuth Verlag, 1966, p. 152: "Siquidem mortuo patre suo comite D. Henrico, cum adhuc ipse puer esset duorum aut trium annorum".

${ }^{90}$ CASSOTI, Marsilio - D. Teresa. A primeira rainha de Portugal. Lisboa: A Esfera dos Livros, 2008, pp. 103-104.

Medievalista online № 19| Janeiro - Junho 2016 @ IEM - Instituto de Estudos Medievais 25 www2.fcsh.unl.pt/iem/medievalista 
tenha dado à luz o seu filho Afonso Henriques. Levando esta presunção até às últimas consequências e dado que os dois documentos condais de 1106 não contêm nenhuma referência semelhante às acima apontadas, podemos admitir que nasceu depois do mês de agosto desse ano. Por outro lado, atendendo à particularidade do Autor da Vita Theotonii considerar ambos os extremos no cômputo dos anos entre duas datas, não podemos excluir a possibilidade de o nascimento ter ocorrido já entrado o ano de 1107.

Os dois documentos condais de 1108, cuja outorga se deve ter realizado em Sahagún, corresponderiam aos primeiros registos que dispomos da apresentação pública do jovem infante, que teria transposto o seu primeiro ano de vida, um facto notável numa época em que a mortalidade infantil era muito elevada. Sabendo que o conde D. Henrique e D. Teresa estavam dispostos a movimentar as suas peças no xadrez da sucessão ao trono de Leão e Castela, o mais provável é que Afonso Henriques tenha nascido na corte. No seu círculo mais restrito, esta era composta pelos membros da família real mais próximos do monarca. Seguir-se-iam os eclesiásticos e magnates, detentores dos principais cargos do reino, os homens de confiança do rei para as tarefas administrativas do Estado e os servidores do palácio. Os historiadores espanhóis concordam que se se pudesse falar de uma capital do reino ao tempo de Afonso VI, ela teria sido Sahagún ${ }^{91}$.

O certo é que o local do nascimento caiu no esquecimento, não sei se pela simples erosão do tempo ou por ser inconveniente para a construção da identidade nacional. As duas referências documentais explícitas de que a condessa $D$. Teresa tinha morada em Guimarães e Viseu, que poderiam ser utilizadas para sustentar o nascimento numa das duas cidades, reportam-se ao tempo da sua viuvez ${ }^{92}$. Uma criação literária transmitida pela Crónica de 1419 refere que Afonso Henriques foi entregue em criança a Egas Moniz, que se deslocou a Guimarães para o efeito. Merece a pena transcrever o texto:

"E o seu nacimento foi na era de mil e cento e trinta e dous anos (sic). Como dom Egas Monis soube que a rainha parira, cavalgou muito azinha e veio-

${ }^{91}$ GARCIA, Charles - "Itinérance de la cour et attaches sédentaires sous Alphonse VI et Urraque I ${ }^{\text {er". }}$ in e-Spania [em linha], 8 de dezembro de 2009, colocado em linha a 21 de fevereiro de 2010. Disponível em: http://e-spania.revues.org/index18692.html.

92 AZEVEDO, Rui de (ed.) - op. cit., t. I, doc. 55 (2 de janeiro de 1121), no qual D. Teresa doou um campo situado "in uilla de Vimaranis et iacet iusta palacium nostrum regale" e doc. 72 (outubro de 1125), que regista a sua execução "in illo palatio de Viseo", respetivamente.

Medievalista online $N^{\circ}$ 19| Janeiro - Junho 2016 @ IEM - Instituto de Estudos Medievais 26 www2.fcsh.unl.pt/iem/medievalista 
sse a Guimarães, onde o conde era, e pediu-lhe por merçe que lhe desse o filho que lhe naçera para o aver de criar assi como prometido lho avia"93.

Ainda que haja um fundo de verdade histórica nessa narrativa e o menino fosse entregue ao «Aio» em Guimarães com, digamos, três anos de idade, a trama dos dados documentais não nos permite deduzir que tenha nascido nessa cidade. O que os historiadores modernos nos transmitiram foi diferente. Manifestando um horror ao vazio que advinha da existência de uma informação muito lacunar, não só não exerciam qualquer juízo crítico sobre as fontes que utilizaram, como faziam deduções hipotéticas que apresentavam como se de uma narrativa certa e segura se tratasse. Vejamos uma passagem da Crónica do conde D. Henrique, de Duarte Nunes de Leão, umbilicalmente ligada ao epíteto de Cidade-Berço:

"Outros que são mais para crer, dizem que [Afonso Henriques] nasceeo em Guimarães aleijado das pernas, que da nascença trouxe encolheitas, \& que Dom Egas Moniz, o pedira ao conde para o criar em sua casa" ${ }^{94}$.

Em plena Guerra da Restauração, os vimaranenses apresentaram uma pia batismal onde atestaram ter sido batizado D. Afonso Henrique, de acordo com o testemunho de um contemporâneo:

“(...) foi baptizado na igreja de S. Miguel, parrochia da villa Araduca, por S. Giraldo arcebispo de Braga, cuja pia baptismal mandou trasladar D. Diogo Lobo da Silveira, em 1664, para a real collegiada da Oliveira, sendo prior della, aonde está em veneração mettida em um nicho na parede da parte da Epístola, guardada com grades de ferro, e um lettreiro na parede que diz: - «Nesta pia foi baptisado el-rei D. Affonso Henriques pelo arcebispo de Braga S. Giraldo»" ${ }^{95}$.

${ }^{93}$ CALADO, Adelino de Almeida (ed.) - Crónica de Portugal de 1419. Aveiro: Universidade de Aveiro, 1998, p. 6.

94 LEÃO, Duarte Nunes de - Primeira parte das chronicas dos reis de Portugal. Lisboa: Pedro Crasbeeck, 1600, f. 12v-13.

95 BRITO, Maria Fernanda Constante de - “«Memórias Ressuscitadas da Antiga Guimarães», pelo Padre Torquato Peixoto de Azevedo. Achegas para um estudo comparativo das três versões desta obra", in

Medievalista online $\mathrm{N}^{\circ}$ 19| Janeiro - Junho 2016 @ IEM - Instituto de Estudos Medievais 27

www2.fcsh.unl.pt/iem/medievalista 
Através de uma adição à memória nacional, convocava-se o fundador para a consolidação da independência. Esta materialização surtiu o efeito desejado para consciência da nacionalidade e ainda hoje se ouve dizer que quem nasceu em Guimarães é português duas vezes.

No século XX, o professor da Universidade de Coimbra Torquato de Sousa Soares defendeu o nascimento do primeiro rei na cidade onde desenvolveu a sua carreira profissional e o historiador lamecense Almeida Fernandes deu como inegável o nascimento do primeiro rei na sua capital distrital. Ambos os investigadores pretendiam apurar o facto com a maior objetividade possível mas anunciaram o que lhes pareceu terem descoberto sem terem feito um levantamento completo das fontes.

Pela minha parte, ainda não encontrei indícios de que D. Afonso Henriques possa ter nascido na minha cidade do Porto, nem sequer no território que daqui houve nome. $\mathrm{O}$ mais credível é que tenha nascido no Reino de Leão e Castela, em Terra de Campos, talvez mesmo em Sahagún. Isso não impede que o reconheçamos como notável caudilho militar e fundador do país que somos.

\section{REFERÊNCIAS BIBLIOGRÁFICAS}

\section{Fontes impressas:}

AZEVEDO, Rui de (ed.) - Documentos Medievais Portugueses, Documentos Régios. Vol. I - Documentos dos condes portucalenses e de D. Afonso Henriques: A-D. 10951185, 2 tomos. Lisboa: Academia Portuguesa de História, 1958-1962.

AZEVEDO, Rui de (ed.) - Documentos Medievais Portugueses, Documentos Particulares. Vol. III - A-D. 1101-1115. Lisboa: Academia Portuguesa de História, 1940.

Actas do Congresso Histórico de Guimarães e sua Colegiada. Vol. III, Comunicações. Guimarães: Congresso Histórico de Guimarães, 1981, p. 462.

Medievalísta online № 19| Janeiro - Junho 2016 @ IEM - Instituto de Estudos Medievais 28 www2.fcsh.unl.pt/iem/medievalista 
BLÖCKER-WALTER, Monica - Annales D. Alfonsi Portugallensium Regis, in Alfons I von Portugal. Studien zu Geschichte und Sage der Begrunders der portugiesichen Unbhangigkeiten. Zurich: Fretz und Wasmuth Verlag, 1966.

CALADO, Adelino de Almeida (ed.) - Crónica de Portugal de 1419. Aveiro: Universidade de Aveiro, 1998.

CAVERO DOMÍNGUEZ, Gregoria e MARTIN LÓPEZ, Encarnación - Colección Documental de la Catedral de Astorga I (646-1126). Léon: Centro de Estudios e Investigacíon San Isidoro/Achivo Histórico Diocesano de León, 1999.

DAVID, Pierre (ed.) - Annales Portucalenses Veteres. in Études Historiques sur la Galice et le Portugal du VI au XII siècle. Lisboa-Paris: Livraria Portugália Editora, Société d'Édition Les Belles Lettres, 1947, pp. 257-340.

ESTEFÂNIO, Abel - "Um documento significativo para a história da Galiza". in Annuarium Sancti Iacobi, 2 (2013), pp. 17-30.

FALQUE REY, Emma (ed.) - Historia Compostelana. Madrid: Ediciones Akal, 1994. FERNÁNDEZ FLÓREZ, José Antonio (ed.) - Coleccion Diplomática del Monasterio de Sahagún (857-1230). T. IV - 1110-1199. León: Centro de Estudios e Investigación «San Isidoro» (CSIC-CECEL), Caja España de Inversiones, Archivo Histórico Diocesano, 1991.

FLÓREZ, Henrique (ed.) - "Historia Compostellana". in España Sagrada. Vol. 20. Madrid, 1765.

GAMBRA, Andrès - Alfonso VI. Cancillería, Cúria y Império. I - Estudio. II Colección Diplomática. León: Centro de Estudios e Investigacíon San Isidoro/Achivo Histórico Diocesano de León, 1997-1998.

HERRERO DE LA FUENTE, Marta (ed.) - Coleccion Diplomática del Monasterio de Sahagún (857-1230). T. III - 1073-1109. León: Centro de Estudios e Investigación «San Isidoro» (CSIC-CECEL), Caja de Ahorros y Monte de Piedad, Archivo Histórico Diocesano, 1988.

Medievalista online № 19| Janeiro - Junho 2016 @ IEM - Instituto de Estudos Medievais 29 www2.fcsh.unl.pt/iem/medievalista 
LEÃO, Duarte Nunes de - Primeira parte das chronicas dos reis de Portugal. Lisboa: Pedro Crasbeeck, 1600.

RODRIGUES, Manuel Augusto; COSTA, Avelino de Jesus da; VELOSO, Maria Teresa Nobre (eds.) - Livro Preto, cartulário da Sé de Coimbra. Coimbra: Arquivo da Universidade de Coimbra, 1999.

Portugaliae Monumenta Historica, Diplomata et Chartae. Vol. I. Lisboa: Academia das Ciências de Lisboa, 1873.

PUYOL Y ALONSO, Julio (ed.) - Las crónicas anónimas de Sahagún: nueva edición conforme un ms. del siglo XVI. Madrid: Establecimiento Tipográfico de Fontane, 1920.

\section{Estudos:}

AMARAL, Luís Carlos e BARROCA, Mário Jorge - A condessa-rainha Teresa. Lisboa: Circulo de Leitores, 2012.

BARÓN FARALDO, Andrés - "Magnates y "nobiles" en la curia del conde Raimundo de Borgoña. "Totius gallecie princeps" (ca. 1091-1107)". in Estudios mindonienses: Anuario de estudios histórico-teológicos de la diócesis de Mondoñedo-Ferrol, 27 (2001), pp. 531-574.

BARRILARO RUAS, Henrique - "Se partio ayrado del rrei". separata da Revista Portuguesa de História, tomo IV. Coimbra, 1955, pp. 5-7.

BARRILARO RUAS, Henrique - "Henrique, conde D.", in SERRÃO, Joel (dir.) Dicionário da História de Portugal. Vol. III. Porto: Livraria Figueirinha, 1971, pp. 192195.

BARROCA, Mário Jorge - "Da Reconquista a D. Dinis". in MATTOSO, José (coord) Nova história militar de Portugal. Vol. 1. Lisboa: Círculo de Leitores, 2003, pp. 21161.

BISHKO, Charles Julian - "Count Henrique of Portugal, Cluny and the antecedents of the Pacto Sucessório". in Revista Portuguesa de História, 13 (1971), pp. 155-188.

Medievalista online № 19| Janeiro - Junho 2016 @ IEM - Instituto de Estudos Medievais 30 www2.fcsh.unl.pt/iem/medievalista 
Reedição, com nota adicional, em Spanish and portuguese monastic history: 600-1300. London, 1984, IX, pp. 166-167.

BRITO, Maria Fernanda Constante de - “"Memórias Ressuscitadas da Antiga Guimarães», pelo Padre Torquato Peixoto de Azevedo. Achegas para um estudo comparativo das três versões desta obra". in Actas do Congresso Histórico de Guimarães e sua Colegiada. Vol. III, Comunicações. Guimarães: Congresso Histórico de Guimarães, 1981, pp. 437-491.

CASSOTI, Marsilio - D. Teresa. A primeira rainha de Portugal. Lisboa: A Esfera dos Livros, 2008.

ESCALONA, Romualdo - Historia del Real Monasterio de Sahagún. Madrid, 1782.

ESTEFÂNIO, Abel - “Os Forais condais de Mangualde e os seus problemas de datação cronológica". in Revista Beira Alta, 74 (2015), no prelo.

ESTEFÂNIO, Abel - "Proposta de aclaração do 'pacto sucessório' à luz de novos dados". Medievalista [Em linha]. No 16 (Julho - Dezembro 2014). [Consultado 18.01.2015]. Disponível em:

http://www2.fcsh.unl.pt/iem/medievalista/MEDIEVALISTA16/estefanio1603.html.

ESTEFÂNIO, Abel - “O 'pacto sucessório' revisitado: o texto e o contexto". Medievalista [Em linha]. No 10 (Julho de 2011). [Consultado 31.01.2015]. Disponível em: http://www2.fcsh.unl.pt/iem/medievalista/MEDIEVALISTA10/estefanio1002.html.

ESTEFÂNIO, Abel - "A data de nascimento de Afonso I". Medievalista [Em linha]. No 8 (Julho de 2010). [Consultado 31.01.2015]. Disponível em: http://www2.fcsh.unl.pt/iem/medievalista/MEDIEVALISTA8/estefanio8002.html.

FERNANDES, A. de Almeida - Viseu, Agosto de 1109, nasce D. Afonso Henriques. Viseu: SACRE/Fundação Mariana Seixas, 2007.

FIGUEIREDO, António Pereira de - "Dissertação XVII. Incerteza do anno em que nasceo ElRei D. Affonço Henriques, e certeza do anno, em que elle começou a reinar".

Medievalista online $\mathrm{N}^{\circ}$ 19| Janeiro - Junho 2016 @ IEM - Instituto de Estudos Medievais 31 www2.fcsh.unl.pt/iem/medievalista 
in História e memórias da Academia Real das Sciencias de Lisboa 9 (1825), pp. 299302.

FLETCHER, Richard A. - The Episcopate in the Kingdom of León in the Twelfth Century. Oxford: Oxford University Press, 1978.

GARCIA, Charles - "Itinérance de la cour et attaches sédentaires sous Alphonse VI et Urraque I $^{\text {er". }}$ in e-Spania [em linha], 8 de dezembro de 2009, colocado em linha a 21 de fevereiro de 2010. Disponível em: http://e-spania.revues.org/index18692.html.

Grande Enciclopédia Portuguesa e Brasileira. Vol. XIII. Lisboa / Rio de Janeiro: Editorial Enciclopédia, s.d., verbete "Henrique (D.)".

HERCULANO, Alexandre - História de Portugal desde o começo da monarquia até ao fim do reinado de Afonso III. Prefácio e notas críticas de José Mattoso. Tomo I. Lisboa: Bertrand, 1989.

MATTOSO, José - D. Afonso Henriques. Lisboa: Temas e Debates, 2007.

MATTOSO, José - História de Portugal. Vol. 2 - A monarquia feudal (1096-1480). Coordenação de José Mattoso. Lisboa: Círculo de Leitores, 2003.

MATTOSO, José - “A primeira tarde portuguesa”. in Revista de Guimarães, 88 (1978), pp. 159-186.

MONTENEGRO, Julia - "Enrique de Borgoña en la Primera crónica anónima de Sahagún". in e-Spania [Online], 19 octobre 2014, posto online no dia 13 Outubro 2014, consultado em 21 Fevereiro 2015. URL: http://e-spania.revues.org/23881; DOI : 10.4000/e-spania.23881.

REAL, Manuel Luís - "Mosteiro de Fráguas no contexto do pré-românico da Beira Interior (Portugal)". in Muçulmanos e Cristãos entre o Tejo e o Douro (Sécs. VIII a XIII). Palmela: Câmaral Municipal de Palmela, Faculdade de Letras da Universidade do Porto, 2005, pp. 275-292.

REILLY, Bernard F. - The Kingdom of León-Castilha under King Alfonso VI, 10651109. Princeton: Princeton University Press, 1988.

Medievalista online № 19| Janeiro - Junho 2016 @ IEM - Instituto de Estudos Medievais 32 www2.fcsh.unl.pt/iem/medievalista 
REILLY, Bernard F. - The Kingdom of León-Castella under Queen Urraca (11091126). Princeton: Princeton University Press, 1982.

RODRÍGUEZ LÓPEZ, Ana - "Sucesión regia y legitimidad política en Castilla en los siglos XII y XIII. Algunas consideraciones sobre el relato de las crónicas latinas castellano-leonesas". in ALFONSO, Isabel, ESCALONA, Julio y MARTIN, Georges (eds.) - Lucha política: condena y legitimación en las sociedades medievales. Lyon: École Normale Supérieure, 2004, pp. 21-41.

SALAZAR Y ACHA, Jaime de - "Contribuición al estudio del reinado de Alfonso VI de Castilla: Algunas aclaraciones sobre su política matrimonial". in Anales de la Real Academia Matritense de Heráldica y Genealogía 2 (1992-1993), pp. 299-336.

SALAZAR Y ACHA, Jaime de - "De nuevo sobre la mora Zaida". in Hidalguia 321 (2007), pp. 225-242.

SOARES, Torquato de Sousa - “Afonso I, D.”. in SERRÃO, Joel (dir.) - Dicionário de História de Portugal. Vol. I. Lisboa: Iniciativas Editoriais, 1975, pp. 36-39.

SOARES, Torquato de Sousa - "O governo de Conde Henrique de Borgonha". in Revista Portuguesa de História 14 (1975), pp. 365-397.

VIDAL ENCINAS, Julio M. e PRADA MARCOS, Ma Encina - "El monasterio y panteón de Alfonso VI en Sahagún: Aspectos históricos y arqueo-antropológicos”. in ESTEPA DIEZ, Carlos, FERNÁNDEZ GONZÁLEZ, Etelvina e RIVERA BLANCO, Javier (ed.) - Congreso internacional "Alfonso VI y su legado”. León: Diputación Provincial de León / Instituto Leonés de Cultura, 2012, pp. 243-281. 


\section{COMO CITAR ESTE ARTIGO}

\section{Referência electrónica:}

ESTEFÂNIO, Abel - "De novo a data e o local de nascimento de Afonso I".

Medievalista [Em linha]. № 19 (Janeiro - Junho 2016). [Consultado dd.mm.aaaa]. Disponível em

http://www2.fcsh.unl.pt/iem/medievalista/MEDIEVALISTA19/estefanio1906.html ISSN 1646-740X.

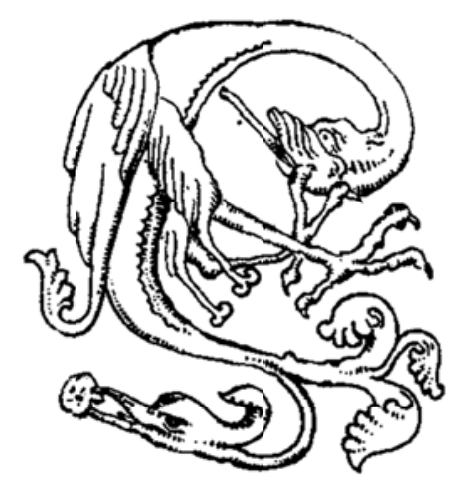

Medievalísta online № 19| Janeiro - Junho 2016 @ IEM - Instituto de Estudos Medievais 34 